University of Nebraska - Lincoln

DigitalCommons@University of Nebraska - Lincoln

USDA Forest Service / UNL Faculty Publications U.S. Department of Agriculture: Forest Service -National Agroforestry Center

\title{
7-1989
}

\section{Reduction of Soil Erosion on Forest Roads}

Edward R. Burroughs, Jr.

John G. King

Follow this and additional works at: https://digitalcommons.unl.edu/usdafsfacpub

Part of the Forest Sciences Commons

Burroughs, Jr., Edward R. and King, John G., "Reduction of Soil Erosion on Forest Roads" (1989). USDA Forest Service / UNL Faculty Publications. 121.

https://digitalcommons.unl.edu/usdafsfacpub/121

This Article is brought to you for free and open access by the U.S. Department of Agriculture: Forest Service -National Agroforestry Center at DigitalCommons@University of Nebraska - Lincoln. It has been accepted for inclusion in USDA Forest Service / UNL Faculty Publications by an authorized administrator of DigitalCommons@University of Nebraska - Lincoln. 
United States

Department of

Agriculture

Forest Service

Intermountain Research Station

General Technical

Report INT-264

July 1989

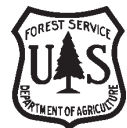

Reduction of Soil Erosion on Forest Roads

Edward R. Burroughs, Jr. John G. King

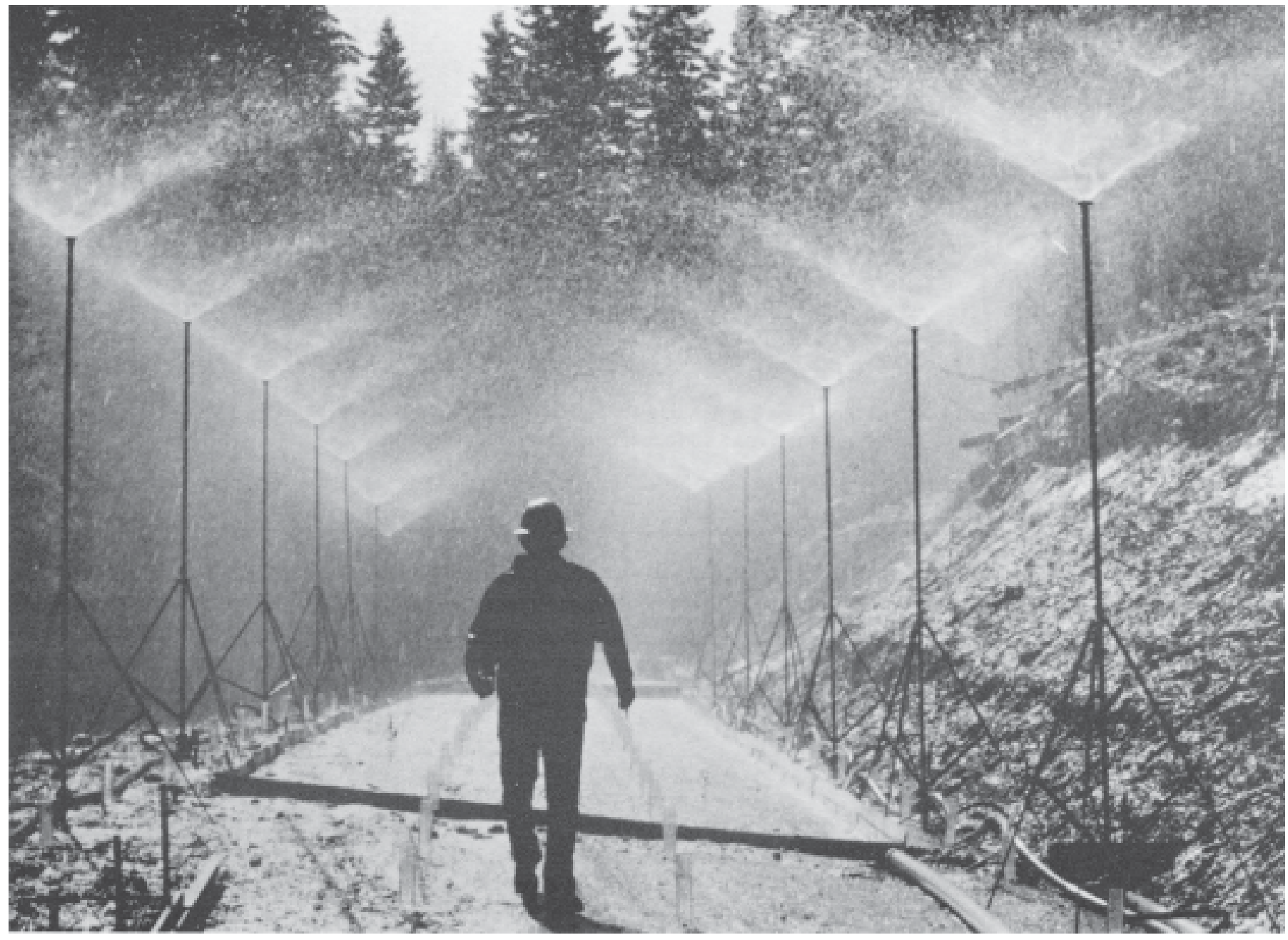




\section{THE AUTHORS}

EDWARD R. BURROUGHS, JR., is a research engineer and leader of the engineering technology project for improved resource management, Intermountain Research Station, Forestry Sciences Laboratory, Moscow, ID.

JOHN G. KING is a hydrologist in a research project to minimize nonpoint source pollution in the Northern Rocky Mountains, Intermountain Research Station, Forestry Sciences Laboratory, Boise, ID.

\section{RESEARCH SUMMARY}

Results of onsite erosion control work from across the United States provide estimates of the amount of erosion reduction on forest roads from various treatments. Supplementary information includes the effects of slope gradient, soil characteristics, and ground cover. Estimates of sediment travel below fillslopes can be made, together with the combined effect of erosion control treatments of the running surface, road cut, and ditch.

\section{CONTENTS}

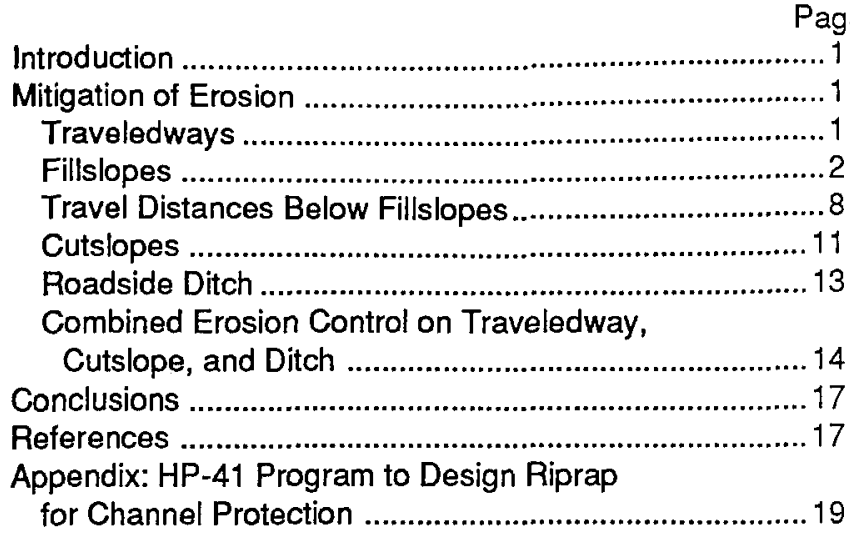

Front cover photo: Researchers use simulated rainfall to measure sediment production from road surfaces, cutslopes, and fillslopes.

The use of trade or firm names in this publication is for reader information and does not imply endorsement by the U.S. Department of Agriculture of any product or service.

Intermountain Research Station

324 25th Street

Ogden, UT 84401 


\title{
Reduction of Soil Erosion on Forest Roads
}

\author{
Edward R. Burroughs, Jr. \\ John G. King
}

\section{INTRODUCTION}

Estimates on erosion reduction were obtained from selected treatments applied to such forest road components as traveledway, cutslope, fillslope, and ditch. Data from the literature and from in-house research reports provide better insight into effective treatments to reduce erosion. These results should have application to revisions of the "Guide for Predicting Sediment Yields from Forested Watersheds" (Cline and others 1981) developed for the Forest Service's Northern and Intermountain Regions. This guide was originally designed as a method to estimate increases in sediment production from watersheds as the result of various land management practices.

The current Sediment Guide for the Northern (R-1) and Intermountain (R-4) Regions allows a percentage reduction in sediment yield from the total road prism as the result of applying a single erosion control practice, or the application of a combination of practices (Cline and others 1981, table 4). These reductions in onsite sediment production from the total road imply a partitioning of total sediment production of about 60 percent from fillslopes, 25 percent from traveledways, and 15 percent from the cutslope and ditch. This partitioning was discovered by comparing erosion reduction factors in the guide with the amount of erosion reduction for individual road prism components as given in the literature cited in the guide's table 4. New information about onsite road sediment is based on studies by the Intermountain Research Station's Engineering Technology and Watershed Management Research Work Units. These studies show that partitioning of sediment production may be significantly different from that used in the guide and can change as a mitigation measure applied to one road prism component influences sediment yield from other components. This report discusses the potential for reduction of onsite sediment production by various treatments on each component of the road prism.

\section{MITIGATION OF EROSION}

Based on our research and the literature, we have compiled a comprehensive study of the mitigation of erosion from specific components of the road prism: traveledways, fillslopes, cutslopes, and roadside ditches. Because the sediment yields from adjacent components are not directly additive, we need also to review studies on combined erosion control for these areas.

\section{Traveledways}

Data on erosion reduction from treated traveledways come from two types of experiments: (1) natural rainstorms and snowmelt on road segments defined by cross drains or dips and (2) simulated rainfall on bordered road segments or small bordered plots. A study of sediment production from treated and untreated road segments subject to natural climatic events was completed by Swift (1984b) in North Carolina. Sediment production in tons per acre per inch of precipitation was measured for bare traveledways before and during timber harvest and also for graveled traveledways subject to light vehicle traffic. These data show that logging traffic on an unsurfaced traveledway can increase sediment production by a factor of 1.90. Our measurements of sediment production from an unsurfaced traveledway in border-zone batholith material with simulated rainfall showed that a surface rutted by a heavy truck will produce 2.08 times the yield of a smooth surface (Burroughs and others 1984). We recommend that the estimated sediment production for a rutted, unsurfaced traveledway be increased by a factor of 2 , relative to the yield from a smooth, unsurfaced traveledway.

Swift's (1984b) study further showed that placement of a 6-inch lift of 1.5-inch minus crushed rock reduced sediment production by 70 percent from the unsurfaced condition over a 5-month period. The gravel achieved this amount of protection even though this period included 6.46 inches of rainfall in 5 days. In 13.3 months, the gravel with established grass at the margins of the traveledway reduced sediment production by over 84 percent compared to 9.5 months when the road was unsurfaced.

Simulated rainfall was applied to two 100 -ft bordered sections of the Rainy Day road, Nez Perce National Forest, built in "border-zone batholith" material of gneiss and schist (Burroughs and others 1985a). One section was left unsurfaced and the other was surfaced with a 4-inch lift of 1.5-inch minus hard gneissic crushed rock. Each section was $13 \mathrm{ft}$ wide with an 8 percent centerline grade and was insloped at 4.4 percent to a standard ditch. Total sediment for the first rainfall application on the gravelsurfaced road section was $64.3 \mathrm{lb}$ from 1.05 inches of rainfall, or $61.2 \mathrm{lb}$ per inch of rainfall. Total sediment from the first rainfall on the unsurfaced road section was $312.1 \mathrm{lb}$ per 1.08 inches of rainfall, or $289.0 \mathrm{lb}$ per inch of rainfall. The reduction in sediment production by graveling this road section was 79 percent, which compares well with Swift's (1984b) results for a section of road protected only by gravel. 
Other data by Swift (1984a) show that the thickness of the gravel layer is important. Two inches of crushed rock (1.5 inch minus) placed on a road built in sandy loam soil showed no sediment reduction over the yield from an unprotected road. A 6-inch lift of crushed rock (1,5 inch minus) reduced sediment yield by about 92 percent, and an 8-inch layer of large stone (3.0-inch $\left.D_{50}\right)$ reduced sediment production by about 97 percent.

A similar study in West Virginia by Kochenderfer and Helvey (1987) tested roads surfaced with 6-inch lifts of 3 -inch washed gravel (size ranged from 1.5 to 3 inches) and 3-inch crusher-run gravel. Average reductions in sediment production were 88 percent and 79 percent, respectively, over an unprotected road during the 4-year measurement period.

Mitigation of sediment production by graveling is a function of the erodibility of both the gravel and the underlying material. Erosion reduction by gravel surfacing is maximized by the use of hard crushed rock over highly erodible subgrade material.

Measurements of sediment production from surfaced and unsurfaced traveledways were made using simulated rainfall on bounded segments of forest roads (Burroughs and others 1983a; Burroughs and King 1985b). Sediment production was measured on three segments of an unsurfaced road built in granitic materials in Silver Creek, ID, and are compared to two road segments surfaced with dust oil and bituminous surface treatment. Dust oil and the bituminous surface treatment reduced sediment production by 85.3 percent and 96.6 percent, respectively (Burroughs and others 1983a) compared to sediment production from unsurfaced roads. There are drawbacks to each of these treatments: dust oil releases volatile chemicals into surface runoff and the surface breaks down easily under heavy traffic; and bituminous surface treatment is expensive. No good data were found on sediment reduction by lime or magnesium chloride.

\section{Fillslopes}

The success in minimizing fillslope surface erosion will depend on the timing of application of any control measure, the type of treatment, the rate of application for mulch treatments, the inherent erodibility of the soil, the slope gradient, and whether or not the road is insloped. This section discusses the effectiveness of various treatments for controling surface erosion on new fillslopes.

Most studies that have measured sediment production from fillslopes over time show that, initially, rates in this unconsolidated material are high and exponentially decrease over time (Megahan 1974; King 1984). For example, figure 1 illustrates the cumulative fillslope sediment production for the first summer and fall following construction of 1.5 miles of road in the Horse Creek watersheds of northern Idaho. This road was completed and sediment production measurements were initiated in midAugust 1978. The fillslopes were hydromulched, seeded, and fertilized in mid-September. During the first 30 days, about 3 inches of rain fell, which included 5 days with amounts greater than 0.3 inches. This was an unusually high rainfall for this period. The average amount of rainfall expected during 30 days in August and September is slightly less than 2 inches. The single largest event was a 0.89 -inch thunderstorm that occurred 5 days after the beginning of measurements. Initially, fillslope sediment production was responsive to rainfall, partially because of the absence of mulch and the availability of easily eroded particles on the unconsolidated fillslopes. About half of the total fillslope sediment production measured over a 2-year period took place in the first summer and fall. Thus, erosion control measures that can be put in place immediately after fillslope construction have a much larger potential to appreciably reduce sediment production compared to measures that are implemented later.

If treatment is delayed following road completion, we suggest that the percentage of erosion reduction be decreased. The time delay in treatment, expected precipitation, and armoring effects should all be considered in estimating a weighted sediment reduction percentage.

We analyzed published data and in-house research results to determine how selected erosion control treatments compared and how their effectiveness was influenced by soil characteristics, slope gradient, and ground cover. We identified six treatments: (1) straw with asphalt tack, (2) straw with a net or mat, (3) straw alone, (4) erosion control mats, (5) wood chips or rock, and (6) hydromulch. Figures 2 through 8 illustrate the increasing effectiveness of each treatment with increasing ground cover. Of lesser importance in these data sets was silt content of the underlying soil and slope gradient. Generally, the steeper the slope and the siltier the soil, the less effective the treatment. The importance of ground cover in reducing surface erosion for any treatment is apparent in the similar shape of curves in figures 2 through 6 . A curve to estimate the application rate for some treatments is also given. For example, to achieve an 80 percent reduction in erosion, estimate the required ground cover from the main curve, then estimate the application rate to attain that ground cover from the application rate curve. For straw mulch alone, an 80 percent erosion reduction would require 96 percent ground cover (fig. 4a), or about 2.9 tons per acre (fig. 4b).

The estimated amount of reduction in sediment can only be achieved on smooth slopes with proper installation and anchoring of the material, especially for mats and nets. Rocks, slope irregularities, or gullies prevent good contact between the slope and the material and reduce their effectiveness. The effectiveness of any mulch may be reduced where frequent frost heave or ground ice occurs.

The curve for hydromulch shown in figure 7 does not show the same relationship between cover and sediment reduction as the other treatments. Because it has short fiber lengths, it is easily detached and transported off the steeper slopes by surface runoff, unless some fiber tackifier is used. Dudeck and others (1967) compared the application of wood cellulose fibers (1,000 lb per acre) alone and with an asphalt emulsion (150 gal per acre of 1:5 emulsion) and reported about a 35 percent decrease in relative erosion using the emulsion.

Figure 8 shows all six treatments plotted on the same graph to better compare their effectiveness. 


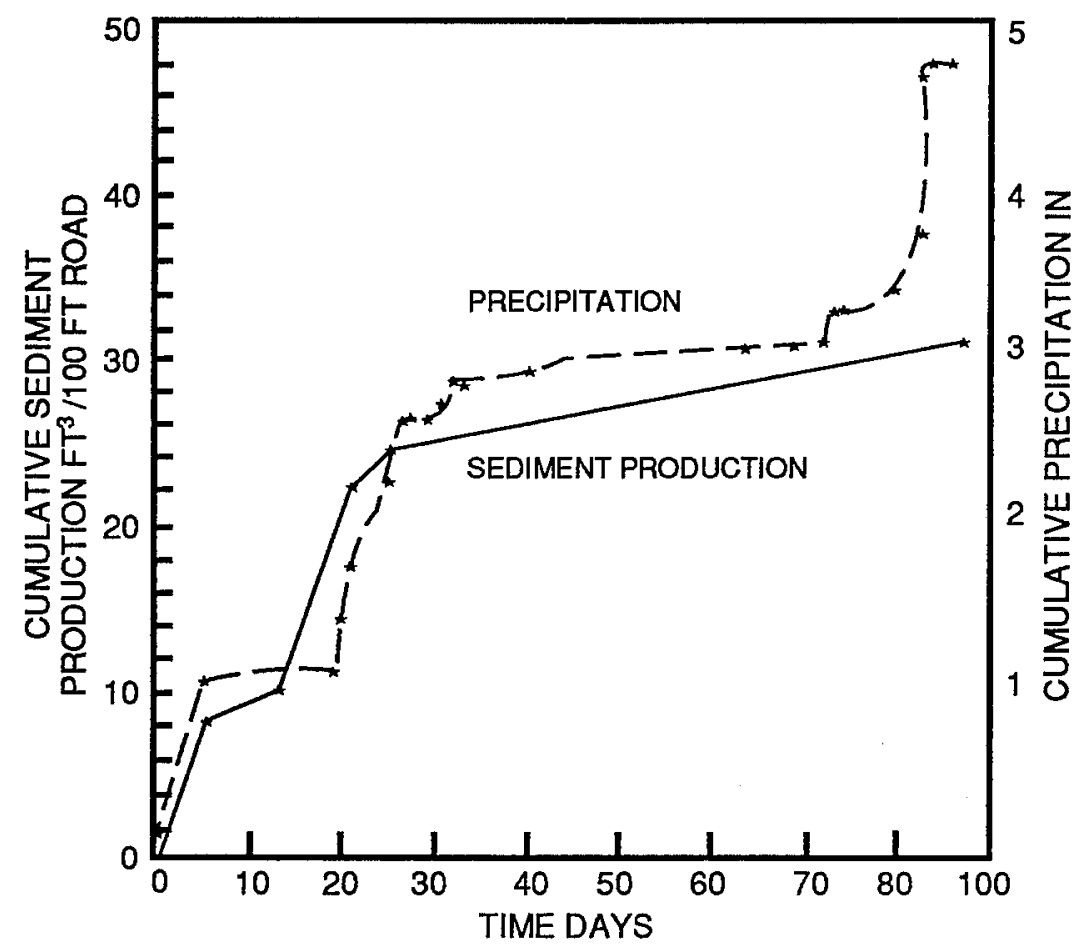

Figure 1-Cumulative fillslope sediment production from rainfall.

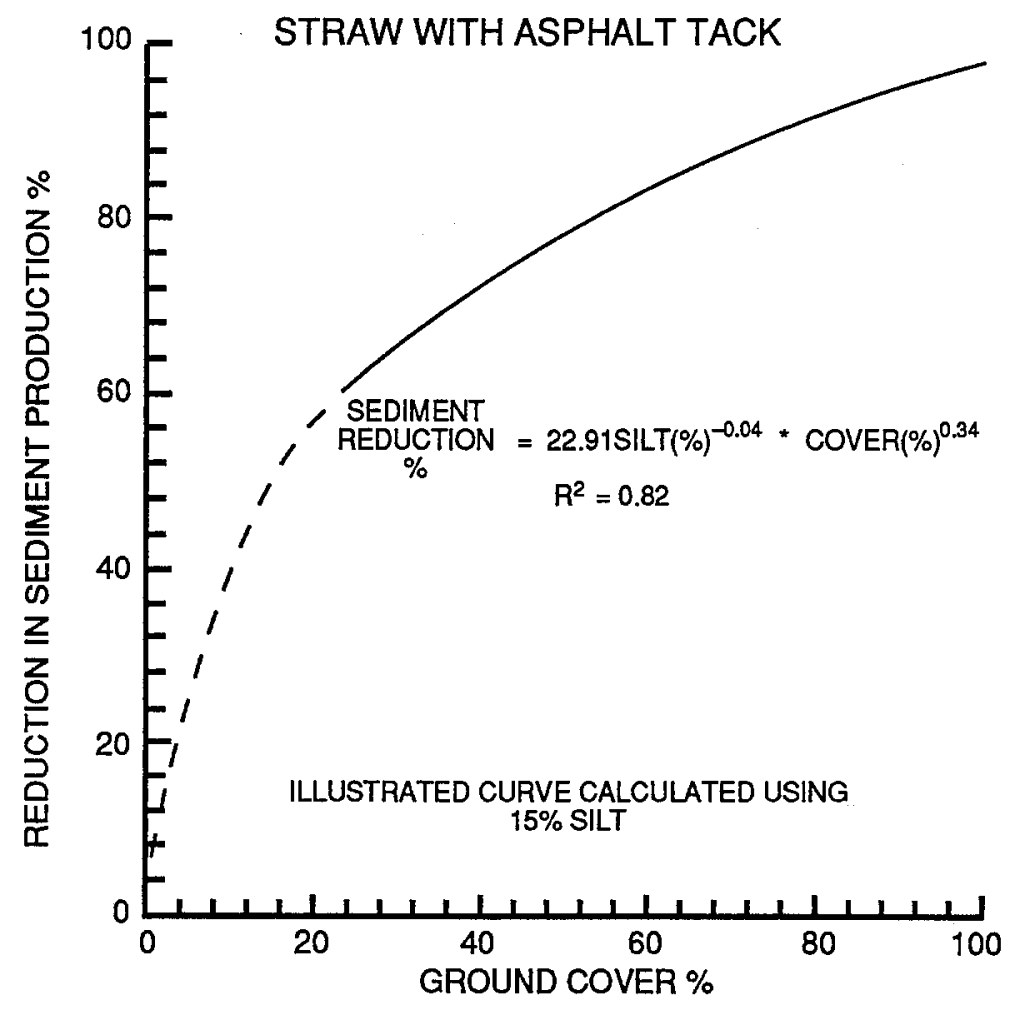

Figure 2-Erosion reduction provided by straw with an asphalt tack (Barnett and others 1967; Dudeck and others 1967; Kay 1984). 


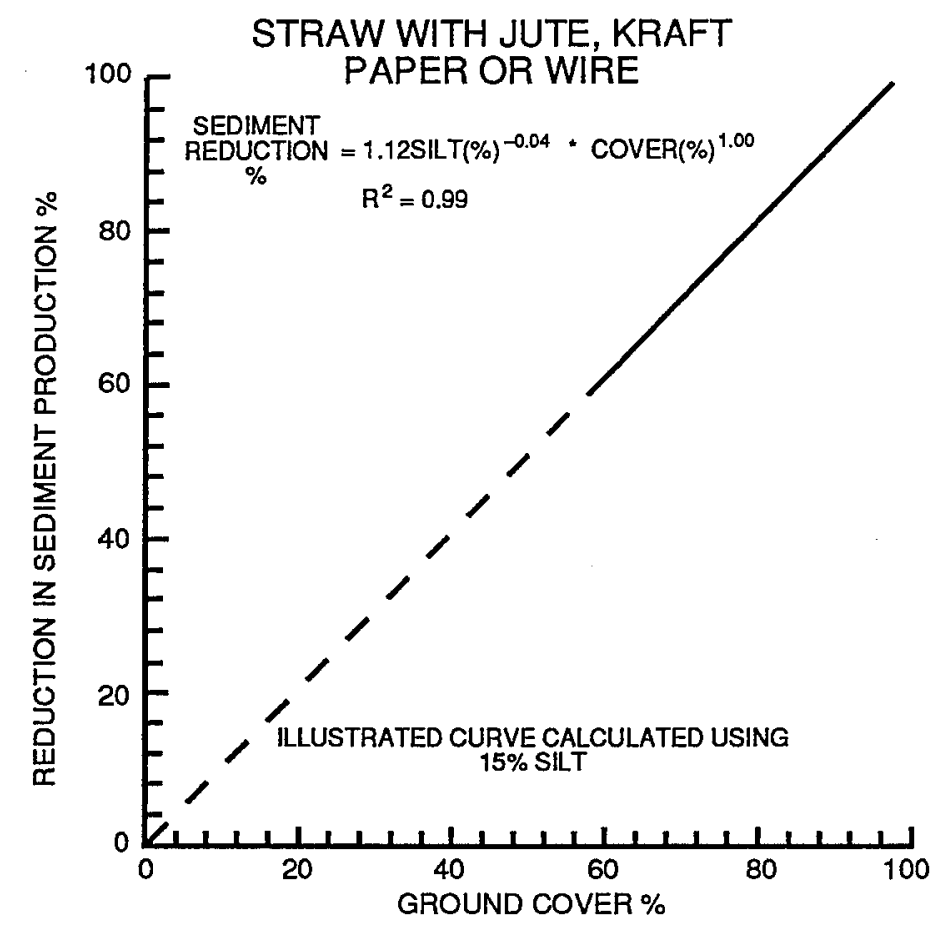

Figure 3-Erosion reduction provided by straw with a net or mat (Bethlahmy and Kidd 1966; Dudeck and others 1967).
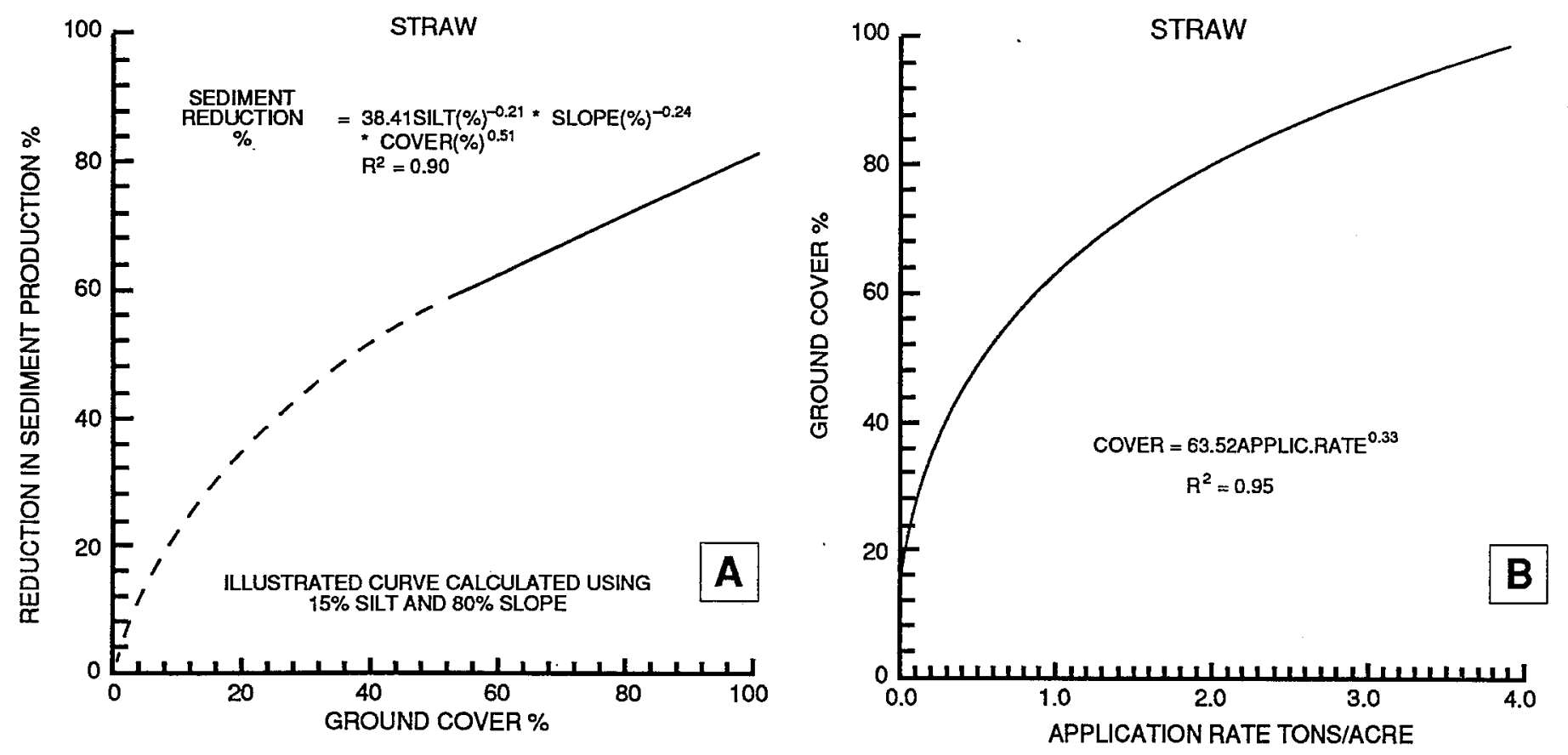

Flgure 4-(A) Erosion reduction provided by straw. (B) Ground cover provided by application rate for all straw treatment. (Barnett and others 1967; Meyer and others 1970; Kay 1984.) 

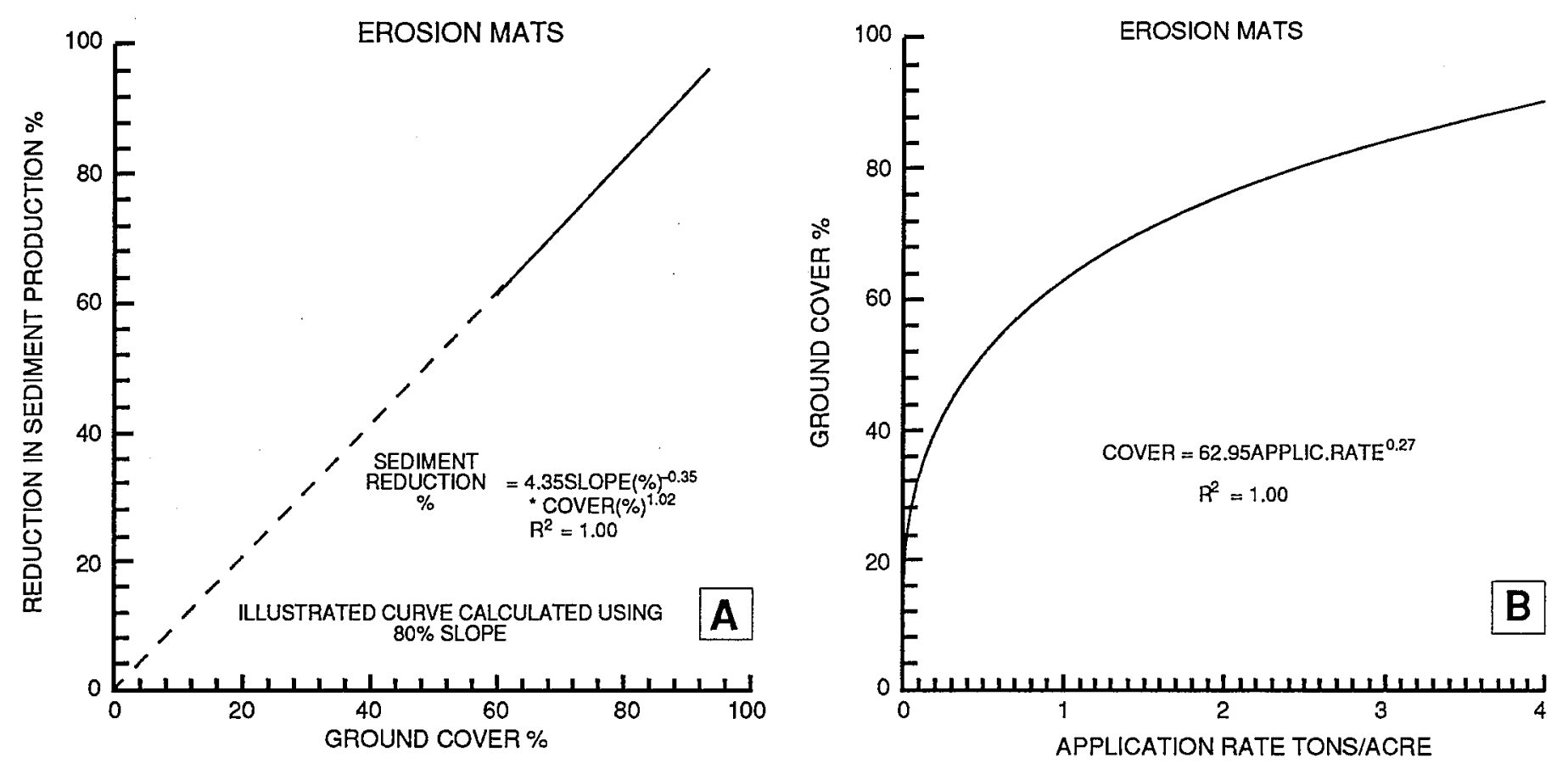

Figure 5-(A) Erosion reduction provided by mats. (B) Ground cover provided by application rate for erosion mats. (Dudeck and others 1967; Gulf Corp. 1977; Kay 1984; Burroughs and King 1985; Burroughs and others 1985.)
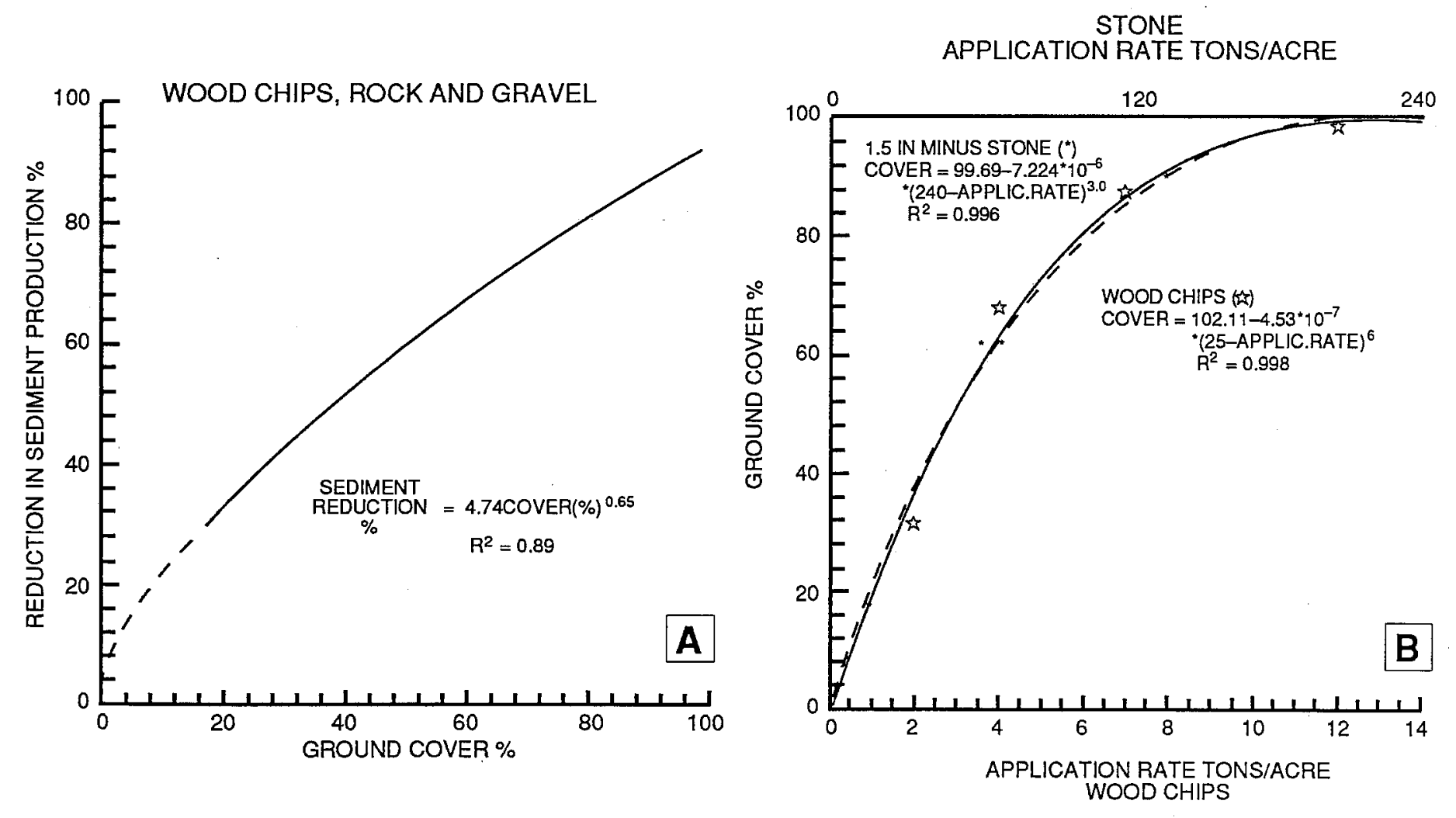

Figure 6-(A) Erosion reduction provided by wood chip or rock mulches. (B) Ground cover provided by application rates for two mulches. (Meyer and others 1972.) 


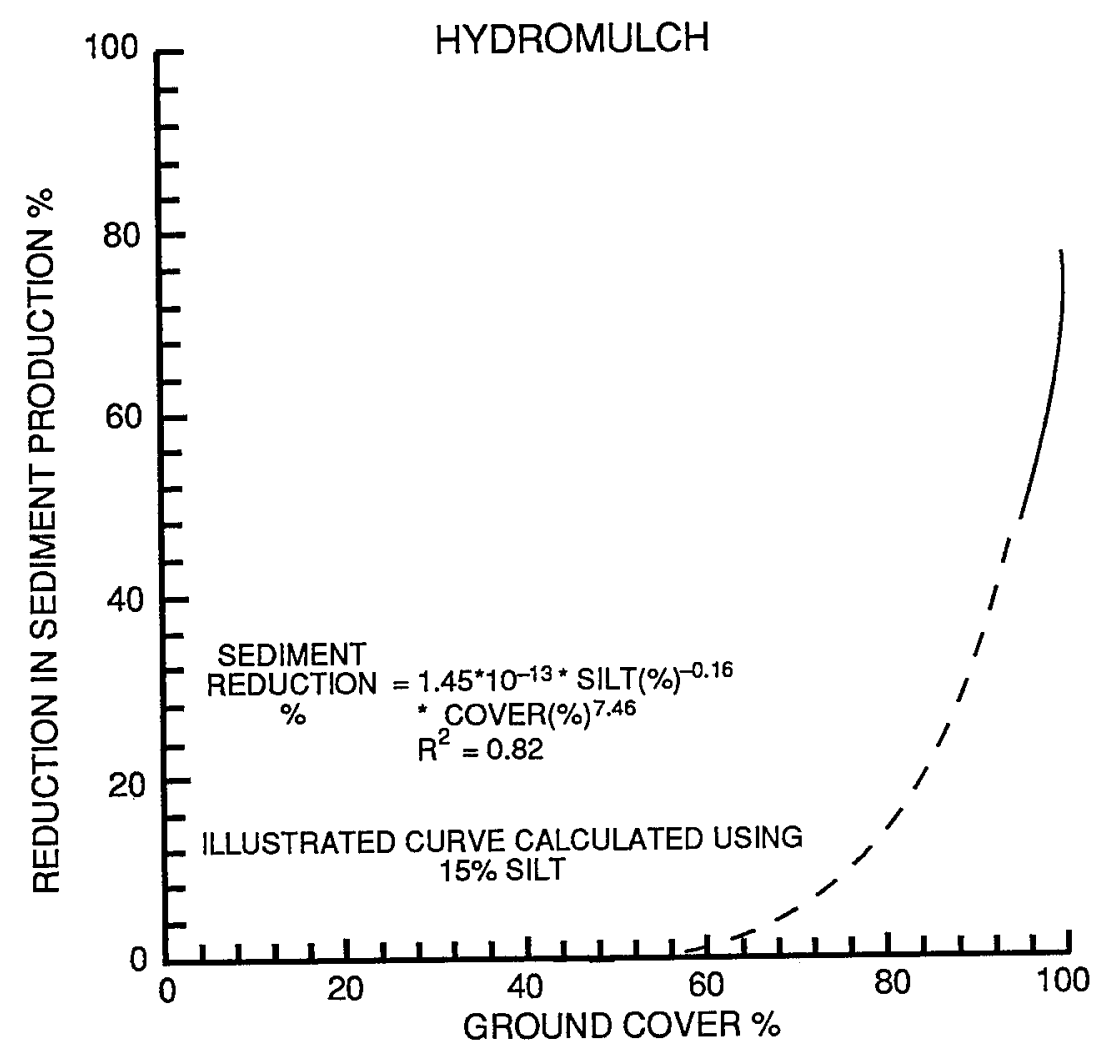

Figure 7-Erosion reduction provided by hydromulch (Dudeck and others 1967; Kay 1984).

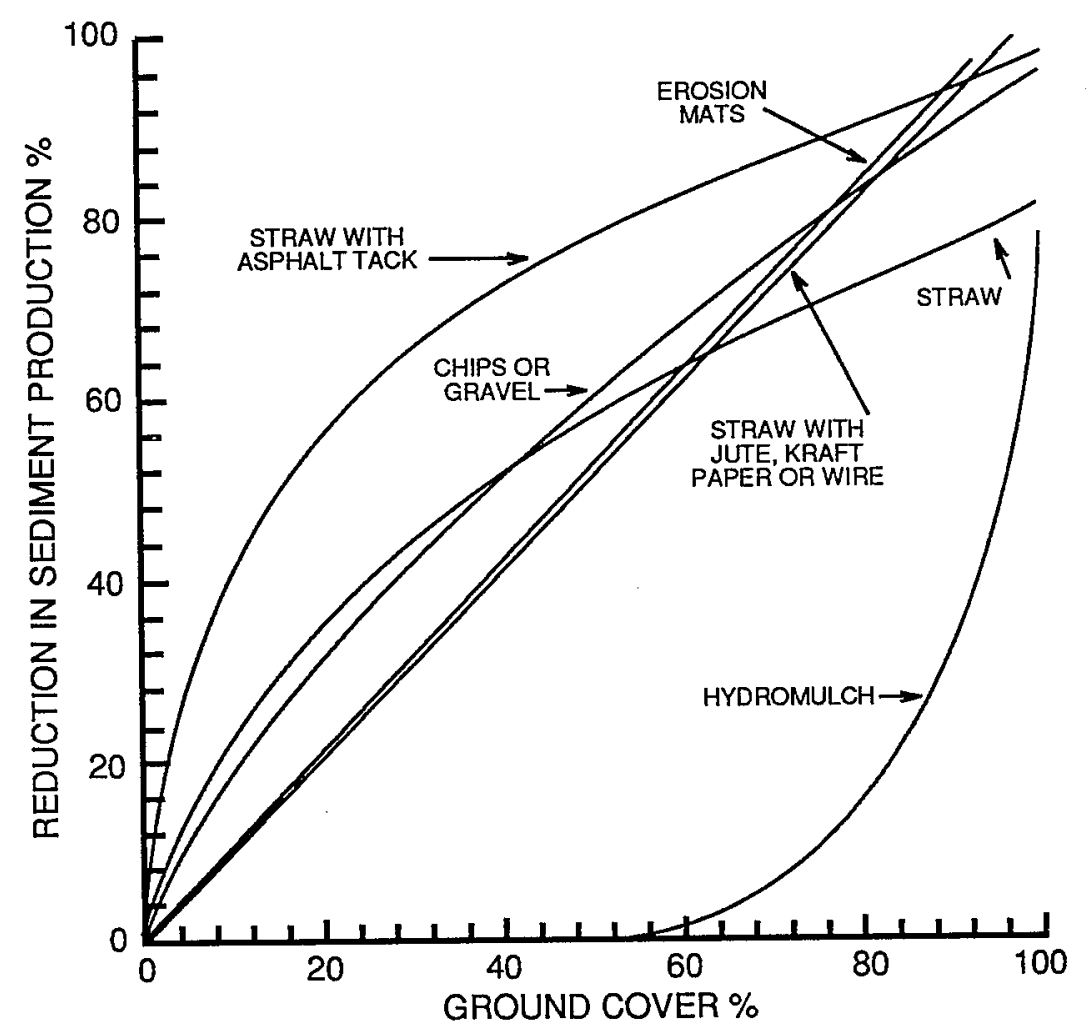

Figure 8-A comparison of erosion reduction provided by selected treatments for average site conditions. 
The effectiveness of any mulch treatment can be reduced if traveledway drainage contributes to the fillslope, promoting accelerated rill and gully erosion. Fillslope sediment production was measured with unbordered plots below crowned traveledways at Horse Creek in northern Idaho (King 1979, 1984). Almost all of the larger gullies in the fillslope were generated from traveledway drainage. This process was more dominant than any sheet or splash erosion process. On fillslopes with a vertical height of less than $20 \mathrm{ft}$, reductions due to seed, hydromulch (1,500 lb per acre), or straw mulch ( 2 tons per acre) with an asphalt tackifier (250 gal per acre) were statistically similar and ranged from 46 to 58 percent over a 3 -year period. The treatment effects were also statistically similar on fills with vertical heights of 20 to $40 \mathrm{ft}$, resulting in only a 24 to 30 percent reduction. For the straw mulch with an asphalt tackifier, the reductions were much smaller than expected because the mulch was not able to protect the fills from concentrated drainage from the traveledway.

Seeding alone does little to control surface erosion until germination and growth of the new plants, and then only if the seed has not been washed from the slope.

Bethlahmy and Kidd (1966) report no sediment reduction from dry seeded and furrowed, steep 1.25:1 decomposed granitic fills in Idaho. In North Carolina, Swift (1984b) collected fillslope sediment data for 9.5 months following road construction and logging, during which the fills were not seeded. These data were compared with the sediment collected during the first 5 and 13.3 months following seeding to show average reductions of 7 and 58 percent, respectively, for these periods as grass became established on the fillslopes.

Wollum (1962) reported results from seeding and fertilizing a 1.25:1 slope on layered tuffs and breccias in western Oregon. Comparison of sediment measured over 1 year from a 6-year-old bare slope to the erosion from the first year after seeding indicates about a 68 percent reduction. In both these studies the comparison is between preseeded and postseeded erosion for the same slope with no separate control slope measurements. Erosion immediately after construction is usually high and diminishes over time as the easily dislodged material is eroded. Thus, the 68 percent (Wollum) and 58 percent (Swift) reductions in sediment are probably too high because of the surface armoring that occurred during the preseeded interval.

Rolling fillslopes was evaluated on the Silver Creek roads for layer-placed, sidecast, and controlled compaction construction. A decrease in the infiltration capacity of the slopes due to compaction by rolling probably generated more surface runoff and subsequently more sediment. Average increases in sediment, compared to nonrolled slopes, ranged from 107 to 532 percent with an average increase for the 11 plots of 282 percent (Boise State University 1984).
Also evaluated on the Silver Creek road fills was an application of a polymer soil binder. The binder initially formed a surface crust, which was broken by frost action and desiccation. Based on data collected by Boise State University (1984), average sediment production from the four polymer-treated plots was about twice that of the control plots. Because the crust prevents any infiltration, surface runoff is increased and erosion begins in any cracks in the crust. Kay (1984) reports that these crusts will not survive frost heaving nor will uncured crusts survive freezing temperatures.

Filter windrows are barriers constructed of logging slash that slow the velocity of any surface runoff, causing deposition of most sediments. They can be constructed on or immediately below the fillslope. The advantage of this treatment is that it can be constructed concurrent with road construction to provide immediate control of fillslope sediment. Filter windrow construction by hydraulic excavator (backhoe) is a cost-effective method to incorporate erosion control into forest road construction. Field evaluation of seven machine-constructed windrows in the Horse Creek watersheds over a 3-year period indicated a 75 to 85 percent reduction in sediment leaving the fillslope compared to adjacent hydromulched slopes (Cook and King 1983). We used data from simulated rainfall on bounded fillslope plots in northern Idaho (Burroughs and others $1985 \mathrm{~b}$ ) to estimate the effectiveness of various erosion control treatments used singly and in combination. Figure 9 shows a sediment reduction of about 88 percent by a hand-constructed filter windrow (same specifications as machine-constructed) for the first rainfall. The Curlex mulch is more effective than the filter windrow, but more expensive to apply. For particularly sensitive sites, such as forest roads above streams with high values for water quality, the combination of a filter windrow with Curlex mulch provides about 99 percent sediment reduction. In North Carolina, Swift (1985) evaluated "brush barriers" in terms of sediment travel distance below fillslopes and the frequency of sediment flows. He found that both the average and maximum sediment travel distances were about half as long below brush barriers as below fillslopes without the barriers, and the number of sediment flows per $1,000 \mathrm{ft}$ of road were reduced by about 35 percent.

Rothwell (1983) used logging debris placed parallel to the contour and spaced 60 to $120 \mathrm{~cm}$ apart on road shoulders, ditches, and cutslopes at three stream crossings. Measurements of total suspended sediment production above and below the road at these three crossings and three control crossings indicated about a 75 percent decrease in storm sediment production as the result of debris barriers. 


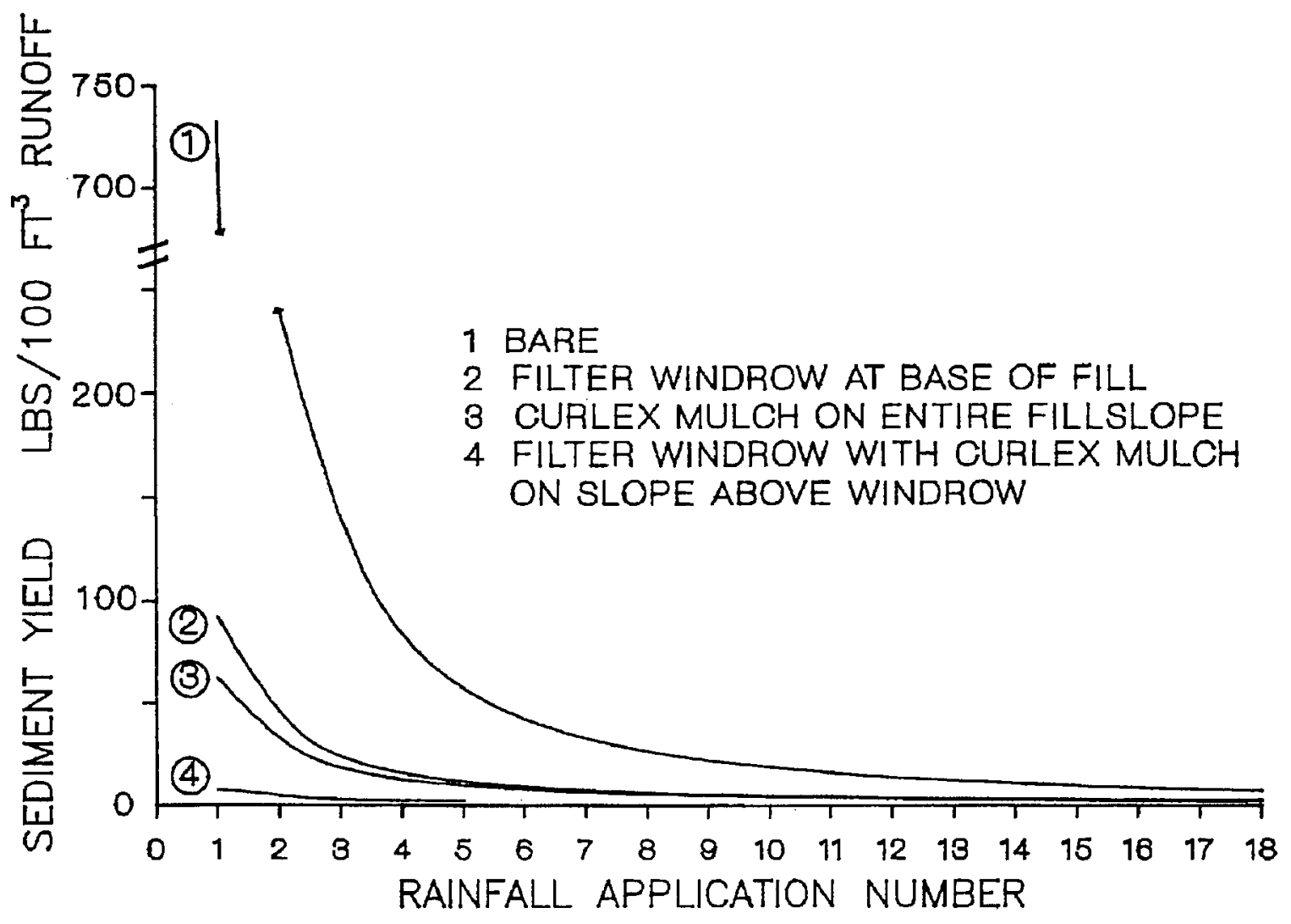

Figure 9-Reductions in sediment production as the result of selected erosion control treatments and surface armoring.

\section{Travel Distances Below Fillslopes}

Although the initial rate of fillslope erosion can be high compared to erosion rates on other road components, it is the transport of eroded material below the fillslopes that determines the degree that streams are affected by fill erosion. For most midslope forest roads, only those fillslopes near stream crossings have a high potential to contribute eroded material to streams. The slope distance required to prevent material from reaching a stream is a function of many interacting site and climatic factors, making it difficult to predict with any degree of accuracy. However, sediment transport distances below fillslopes at the Horse Creek and Gospel Hump sites in northern Idaho provide insight into relationships between transport distance and several site characteristics.

For 1.5 miles of road constructed in Horse Creek in 1978 , rills and gullies formed in the fillslopes were inventoried and transport distances measured each spring and fall through the fall of 1980 . Table 1 shows the average transport distances measured in the fall of 1980 for various categories of fillslopes. We excluded from this summary rills and gullies that contributed sediment to streams and rills that displaced less than $1 \mathrm{ft}^{3}$ of soil. The average transport distance below fillslopes with filter windrows of slash was about $4 \mathrm{ft}$. Typically, material was transported over the windrows in the spring when they were partially buried by the remaining snowpack rather than through the windrow. Of the 45 rills that formed in the windrowed fillslopes, only seven had sediment flows below the windrows. The maximum transport distance was $33 \mathrm{ft}$.

Those situations that resulted in the longest average transport distance were rills formed in slumped material and rills either below relief culvert outflows or rills whose flow paths combined with culvert flow paths. Respective average transport distances for these two situations were 80.4 and $72.8 \mathrm{ft}$.

Most common were rills formed in fillslopes that were not windrowed, had not slumped, and were not influenced by relief culvert flows. The transport distance was influenced by whether the traveledway contributed concentrated runoff to the fillslopes. Average transport distances were about $26 \mathrm{ft}$ if not influenced by traveledway runoff and increased to about $59 \mathrm{ft}$ for instances influenced by concentrated traveledway runoff. An obvious rill had to have formed in the subgrade above the fillslope rill before it was classified as influenced by traveledway runoff. Outsloping of the traveledway was not a classification criteria.

These data provide estimates of distances required between fillslopes and streams to minimize transport of fillslope-derived sediment to the streams. These data also illustrate the effectiveness of slash windrows in reducing 
Table 1-Average transport distance of eroded fill material for Horse Creek road 9704

\begin{tabular}{|c|c|c|c|}
\hline Category & $\begin{array}{c}\text { Average } \\
\text { transport distance }\end{array}$ & $\begin{array}{l}\text { Maximum } \\
\text { transport distance }\end{array}$ & $\begin{array}{c}\text { Number } \\
\text { of rills }\end{array}$ \\
\hline & \multicolumn{2}{|c|}{$\ldots \ldots \ldots+\ldots, \ldots \ldots$} & \\
\hline Windrowed fillslopes & 3.8 & 33 & 45 \\
\hline $\begin{array}{l}\text { Nonwindrowed, no traveledway } \\
\text { drainage, nonslumped, does not } \\
\text { combine with culvert flows }\end{array}$ & 25.8 & 86 & 112 \\
\hline $\begin{array}{l}\text { Nonwindrowed, with traveledway } \\
\text { drainage, nonslumped, does not } \\
\text { combine with culvert flows }\end{array}$ & 58.8 & 85 & 25 \\
\hline $\begin{array}{l}\text { Nonwindrowed, slumped and } \\
\text { nonslumped, combined with } \\
\text { culvert flow paths }\end{array}$ & 72.8 & 125 & 25 \\
\hline $\begin{array}{l}\text { Nonwindrowed, formed in } \\
\text { slumped material, not combined } \\
\text { with culvert flow paths }\end{array}$ & 80.4 & 106 & 30 \\
\hline
\end{tabular}

transport distances and the importance of preventing concentrated traveledway runoff from being diverted onto fillslopes.

The Gospel Hump sites are on 25 road sections on the Nez Perce National Forest of Idaho (Carlton and others 1982). Rill and gully transport distances were measured along a 200-ft road segment at each site the second fall following construction. Additional measurements included the volume of eroded material in each rill, the slope of the fill and the forest floor, the length and height of the fill, the bulk density and particle size distribution of the fill material, the portion of the traveledway that contributed runoff to the fill, and an estimate of obstructions on the forest floor below the road. Obstruction density was a qualitative index from 0 to 6 with 6 representing the highest density of obstructions, such as slash, shrubs, and depressions. The reported linear regression model for estimating transport distance using many of these variables explained only 36 percent of the variation in the data. Although this variation is quite large, several important factors become apparent when the transport distance data are averaged for different obstruction index values and traveledway contributions (fig. 10). As the obstruction index below the fillslopes increases, the average transport distance decreases considerably. This relationship is an oversimplification because gully size may also influence sediment transport distance. Average transport distance was also affected by contributions of drainage from the traveledway. As shown in figure 10, in most instances traveledway drainage to the fills results in longer sediment transport distances.

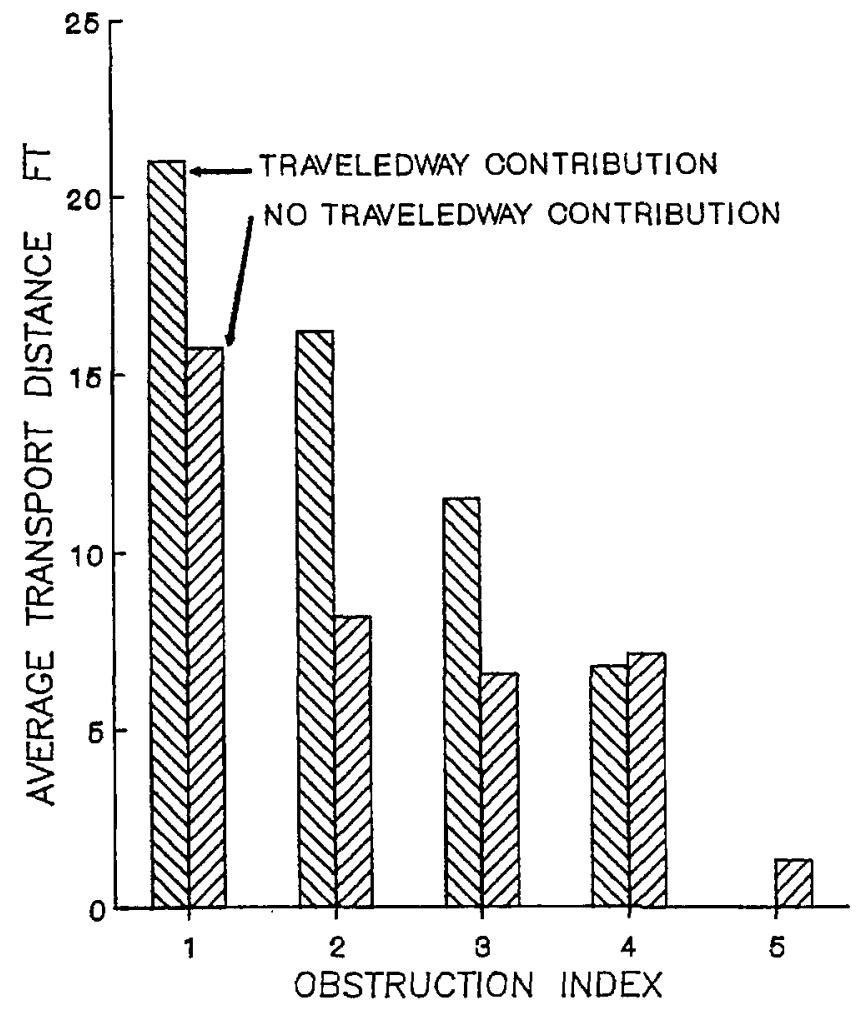

Figure 10-Sediment transport distance below road fillslopes as influenced by obstructions to trap sediment. 
The cumulative frequency of sediment transport distance for the Horse Creek roads are shown in figure 11. Only transport data from Horse Creek fills that were not windrowed, not slumped, and did not combine with culvert flow paths were used for this comparison. Although the range of sediment transport distances remains similar, traveledway runoff shifts the cumulative curve toward the longer distances. For example, less than 10 percent of the rills not influenced by traveledway runoff had transport distances greater than $50 \mathrm{ft}$ compared to about 70 percent of the rills that were influenced by runoff from the traveledway.

In the fall of 1980, transport distances were also measured for sediment flow paths below all relief culverts for the 7.2 miles of Horse Creek roads constructed in 1978 and 1979. Those sediment flow paths that reached streams were excluded from this analysis. At each relief culvert, additional measurements were made of contributing length(s) of road to the culvert and their corresponding centerline gradients and the gradient of the forest floor below the relief culvert along the sediment flow path. Transport distances were not strongly correlated to any of these variables (table 2).

The mean transport distance is not useful because the population of transport distances is skewed to extreme values. The cumulative frequency for sediment transport distance is more useful for planning. Figure 12 shows the predicted cumulative frequency for sediment transport distances. This curve was developed from the measured transport distances of sediment below 70 relief culverts. This relationship can be mathematically expressed as:

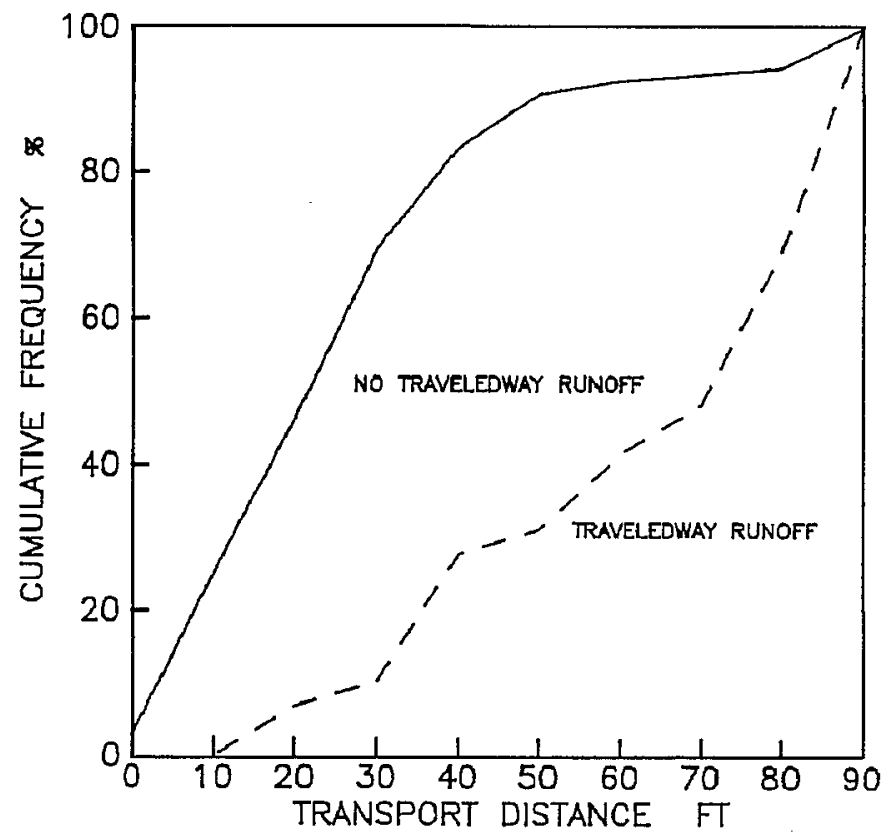

Figure 11-Cumulative frequency of sediment transport distances below fillslopes without the influence of slumps, filter windrows, or culvert outflow.

$$
\begin{aligned}
& Y=98.9048-9.904410^{-13} \cdot(625-X)^{5} \\
& R^{2}=0.99 \\
& \text { where } \\
& Y=\text { cumulative frequency (percent) } \\
& X=\text { transport distance }(\mathrm{ft}) .
\end{aligned}
$$

This relationship shows that for the Horse Creek roads, over half of the relief culverts had sediment transport distances exceeding about $75 \mathrm{ft}$. If the objective is to prevent 80 percent of the relief culverts from contributing sediment to streams, a distance of at least $175 \mathrm{ft}$ must be provided between the culvert outfall and the nearest live water. This relationship probably varies substantially from place to place. However, because of the scarcity of

Table 2-Averages and ranges of data for sediment transport distance below relief culverts along the Horse Creek roads, fall 1980, and selected site characteristics

\begin{tabular}{lcccc}
\hline & $\begin{array}{c}\text { Weighted } \\
\text { road gradient }\end{array}$ & $\begin{array}{c}\text { Total road } \\
\text { length }\end{array}$ & $\begin{array}{c}\text { Forest } \\
\text { floor slope }\end{array}$ & $\begin{array}{c}\text { Transport } \\
\text { distance }\end{array}$ \\
\hline & Percent & $F t$ & Percent & $F t$ \\
Average & 5.5 & 299 & 41 & 127 \\
$\begin{array}{l}\text { Range } \\
\text { Correlation } \\
\text { coefficient }\end{array}$ & $0.3-10.8$ & $40-770$ & $5-73$ & $0-639$ \\
\hline
\end{tabular}

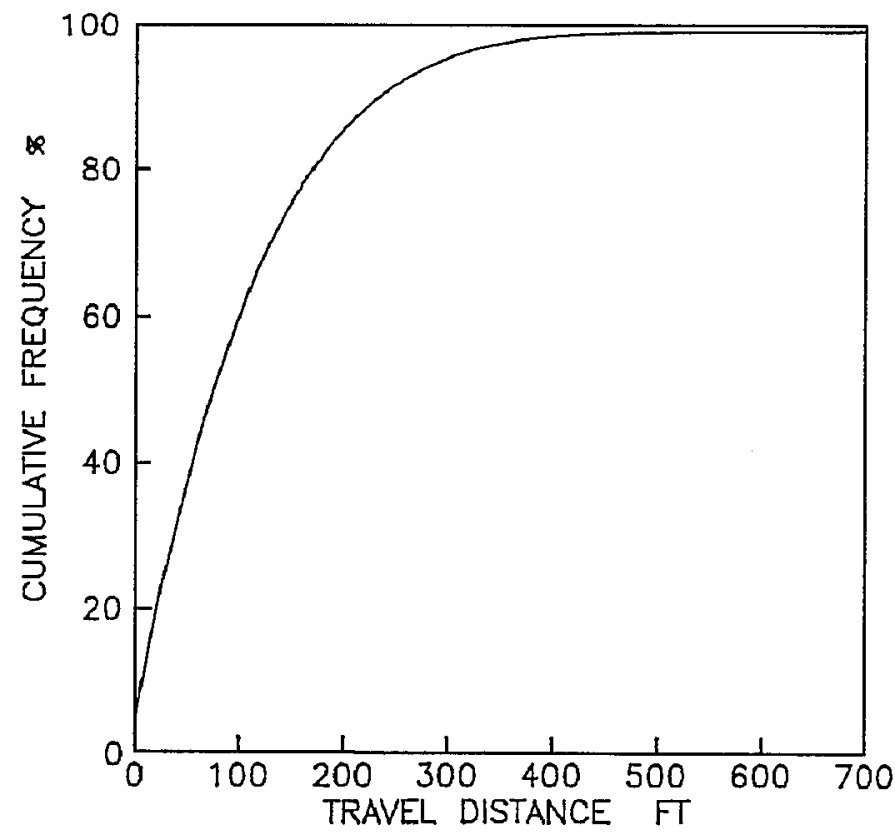

Figure 12-Cumulative frequency of sediment travel distances below fillslopes with the influence of relief culverts. 
this type of data, this information could be used to estimate leave strip widths below roads on sites similar to those in Horse Creek; gneiss and schist parent material and 30 to 40 percent side slope gradients.

\section{Cutslopes}

Many of the same variables that affect fillslope surface erosion control are also applicable to the control of cutslope erosion: type of erosion control treatment, application rate for mulch treatments, the timing of treatment, slope gradient and length, and the inherent erodibility of the soil. The literature and other research results provide little information on erosion control treatments designed specifically for cutslopes. The same erosion control treatments may be used on both fillslopes and cutslopes, with the exception of wood chips and rock mulches, and hydromulch, which may not be suitable for steep cutslopes. Research on the effectiveness of these treatments often includes data from sites with slope gradients similar to cutslopes, that is, 80 to 100 percent. We will assume that estimates of erosion control effectiveness given in figures 2 through 5 will apply to both fillslopes and cutslopes. Exceptions to this general rule will be discussed where local data, experience, and observations indicate some treatments are less effective under certain conditions.

Cutslope erosion processes are often quite different from those on the fillslopes with gentler gradients. Dry raveling during the summer months is a dominant process on cutslopes, especially on noncohesive soils (Megahan 1978). In Oregon, Dyrness (1975) found that dry ravel sediment production of cutslopes in tuffs and breccias was almost as large as rain-generated sediment. Cutslope sediment production from the coarse sand Idaho Batholith soils was usually two to five times higher during the summer and early fall than during the remainder of the year (Boise State University 1984). However, the partitioning between dry ravel and rain-caused sediment was not measured. Bank sloughing when soils are saturated, especially during spring snowmelt, may produce larger soil losses than dry ravel on cohesionless soils. Of the total 2-year cutslope sediment production from borderzone gneisses and schists in the Horse Creek watersheds (Nez Perce National Forest), 80 percent was produced from November through mid-June and 20 percent during the summer and early fall. King and Gonsior (1980) observed that bank sloughing during saturated soil conditions was the dominant process.

As for fillslopes, if erosion control measures are delayed following road construction, the first-year percentage reduction in sediment for the treatment should be decreased.

Dry seeding alone provides no slope protection until germination and growth of the young plants. However, if the seed remains on the cutslope and germinates, then substantial reductions in erosion can occur. A comparison of Swift's (1984b) sediment production data for 9.5 months prior to seeding and 13.3 months following seeding, liming, and fertilization of the same cutslope, indicates an 89 percent reduction in cutslope sediment production.

Dyrness (1975) measured sediment production from 1:1 cutslope plots in western Oregon established on tuffs and breccias. Comparison of sediment production for the first year from the bare control plot and one plot that was dry seeded and fertilized indicated about a 36 percent reduction following seeding. This represents a reasonable expectation for first-year reduction in cutslope sediment provided by grass seeding.

Observations on the Nez Perce National Forest suggest that dry seeding is often not successful on $0.75: 1$ cutslopes unless the vertical height is less than 6 to $8 \mathrm{ft}$. However, dry seeding will produce good stands of grass if slopes can be laid back to a 1:1 or more gentle gradient (Kennedy 1986). We recommend that a 10 percent, first-year reduction in sediment be used for dry-seeding on 0.75:1 slopes with vertical height greater than $8 \mathrm{ft}$, and a 36 percent, first-year reduction on new cutslopes with a slope of $1: 1$ or less.

First-year sediment reductions for new 1:1 cutslopes on tuffs and breccias in Oregon treated with 2 tons per acre of straw mulch averaged about 85 percent (Dyrness 1975). Three treatments included straw mulch and different seed mixtures, and one treatment was only straw mulch. This average decreased slightly over time, and for the second through seventh year of evaluation, the reduction in sediment averaged 77 percent. The slope length for these plots was 20 to $25 \mathrm{ft}$.

Straw mulch applied with a tackifier is substantially more effective in reducing cutslope sediment production than just straw mulch. In the Horse Creek watersheds, a straw mulch ( 2 tons/acre) with asphalt tackifier (250 gal/acre), seed (25 lb/acre) and fertilizer application (100 lb/acre of 24-16-0) on 0.75:1 new cutslopes in borderzone gneiss and schist material reduced sediment by 32 to 47 percent over a 3-year period (King 1984). Vertical heights of these cutslopes ranged from about $3 \mathrm{ft}$ to over $40 \mathrm{ft}$. On slopes laid back to 1.25:1, there was little rilling or deposition in the ditch, and the resulting stand of grass was nearly uniform. Sediment reduction on these gentler slopes probably exceeded 90 percent.

Goss and others (1970) qualitatively ranked the erosion control effectiveness of various treatments on highway fill and cutslopes and in reducing rill, sheet, and slump erosion for various slope gradients (1:1 to $3: 1)$. For $1: 1$ slopes, these rankings are shown in table 3 . The straw with asphalt tackifier was judged to be effective in controlling sheet and rill erosion, and straw mulch alone was slightly less effective. The ability to reduce slump erosion was rated substantially lower. For straw mulch ( 2 tons/ acre), we recommend using sediment reduction percentages of 35 percent for 0.75:1 slopes and 40 percent for slopes at or less than a 1:1 gradient. If an asphalt tackifier is used with the straw mulch, we recommend 40 percent for $0.75: 1$ slopes and 75 percent for $1: 1$ or less steep slopes. Frost heaving or ground ice will displace portions of the mulch and reduce its effectiveness. 
Table 3-Erosion control effectiveness of various treatments on 1:1 slopes (adapted from Goss and others 1970)

\begin{tabular}{lccccccc}
\hline $\begin{array}{c}\text { Erosion } \\
\text { type }\end{array}$ & $\begin{array}{c}\text { Jute } \\
\text { net }\end{array}$ & $\begin{array}{c}\text { Excelsior } \\
\text { mat }\end{array}$ & Straw & $\begin{array}{c}\text { Straw and } \\
\text { asphalt }\end{array}$ & Asphalt $^{\text {Asphydromulch) }}$ & $\begin{array}{c}\text { Wood fiber } \\
\text { (hydrom }\end{array}$ \\
\hline Sheet & 9 & 10 & 8 & 10 & 6 & 3 & 10 \\
Rill & 6 & 10 & 8 & 10 & 6 & 3 & 10 \\
Slump & 10 & 8 & 6 & 7 & 3 & 3 & 8 \\
\hline
\end{tabular}

$110=$ most effective; 1 = not effective.

2Application rate for asphalt is $968 \mathrm{gal} / \mathrm{acre}$ for asphalt alone and $400 \mathrm{gal} / \mathrm{acre}$ when applied with straw.

sApplication rate of $1,200 \mathrm{lb} / \mathrm{acre}$.

In the summer of 1985 , two types of erosion control mats were evaluated on 1:1 cutslopes with vertical heights of 8 to $12 \mathrm{ft}$. Observations of the sediment leaving the mulched cutslopes compared to sediment concentration data collected from bare slopes during simulated rainfall suggest erosion reductions of about 98 percent. These tests were conducted on border-zone gneiss and schist material on the Nez Perce National Forest. The trade names of these erosion mats are: MIRAMAT, a plastic net-type mat; and HOLD/GRO, a nylon-reinforced paper mulch. Because these were tested under simulated rainfall conditions, no evaluation was possible of their ability to control bank slough or slumping during saturated soil conditions. Swift (1987) in North Carolina observed negligible sediment from an excelsior mat reinforced with nylon netting placed over a newly seeded cutslope. One concern about the use of erosion mats on cutslopes is whether the weight of winter snowpack will drag the mat off the slope. Oux observations of MIRAMAT and HOLD/GRO after two winters showed no displacement on the cutslope. The recommended sediment reduction for MIRAMAT and HOLD/ GRO on 1:1 slopes is 95 percent. We assume that mass wasting processes cannot be controlled by these cutslope treatments.

In Washington, Goss and others (1970) report effective surface erosion control on 1:1 slopes using jute net mulches and excelsior matting. The performance of any mat or netting will depend on the uniformity of the slope. For example, Goss and others (1970) noticed some rill erosion under jute netting where good contact with the ground was not achieved during application. We have insufficient data to estimate the effectiveness of jute netting. For excelsior mats, we recommend a sediment reduction of 75 percent on 1:1 cutslopes and 60 percent reduction on $0.75: 1$ slopes.

The Missoula Equipment Development Center, USDA Forest Service, evaluated geotextile and geogrid systems that could be used for revegetating slopes (Tour 1985). They concluded that unless the vertical height of the slope is under $15 \mathrm{ft}$, slopes steeper than 1:1 should not receive mat-type erosion control applications. This conclusion was not based on erosion control effectiveness, but rather on time and labor requirements and practicality of application.

Terracing is quite effective in reducing the amount of soil leaving the cutslopes. Cutslope erosion may still be high, but eroded soil is deposited on the level terraces rather than transported off the slopes. Megahan (1984) reported that terraced and hydroseeded cutslopes constructed in Idaho Batholith granitics resulted in an 86 percent reduction in sediment production. These cutslope gradients ranged from 0.95:1 to 1.38:1. In California, Wagner and others (1979) showed that laying back a 2:1 highway cutslope to a 1.5:1 gradient and terracing the slope in decomposed granitics reduced erosion by about 94 percent. We recommend that 86 percent erosion reduction be used when new cutslopes are terraced.

Hydromulching is not very effective on steep cutslopes. Only a 10 percent reduction (not statistically significant at $\alpha=0.1$ ) in sediment was realized over 3 years on $0.75: 1$ cutslopes on the Horse Creek watersheds. Vertical heights of these slopes were usually less than $20 \mathrm{ft}$. Bank sloughing during saturated soil conditions produced more sediment than surface erosion processes, and hydromulch is not an effective control for mass erosion. Goss and others (1970) ranked wood fiber effectiveness on 1:1 slopes low for controlling rill, sheet, or slump erosion (table 3 ). We recommend using a 10 percent sediment reduction for hydromulch on 0.75:1 slopes and 30 percent for $1: 1$ and less steep cutslopes.

Established stands of dense grass are effective in reducing erosion. An established grass stand has at least 70 percent vegetative ground cover, including plant basal area and litter.

Once grass is established on the cutslope, the recommended sediment reduction is 86 to 100 percent, depending on ground cover density. For the sixth through 14th months following seeding of sandy loam cutslopes in North Carolina, the sediment production rates were reduced 97 percent compared to the 9.5 months after construction and before cutslopes were seeded (Swift 1984b). In Oregon, an average 86 percent reduction was achieved on four newly constructed and seeded cutslope plots (three plots were also mulched) compared to a control plot, for the second through seventh year after seeding (Dyrness 1975). The same treatments on a 5-year-old eroding cutslope resulted in a net soil gain in the second through the fifth year averaging about 0.18 inch compared to a net loss of 1.55 inches from the control plot.

All of the previously discussed cutslope erosion control treatments will vary in effectiveness from site to site. Aspect, elevation, soil type, and the occurrence of frost heaving may all be important factors, but little information is available in the literature to develop any relationships with treatment effects. Additionally, ditch maintenance may 
often undercut the slopes, rejuvenating the erosion process. To reiterate, local experience and observation should be used for application of the recommendations in this section.

\section{Roadside Ditch}

Reduction of sediment production from road traveledways and cutslopes, through mitigation treatments, allows water with lowered sediment concentration to flow down the ditch. This relatively clean ditch water has increased capacity to detach soil from the ditch bottom and transport it to the stream crossing.

Several methods are used to prevent erosion of the ditch bottom, ranging from paving to mats of plastic, jute, or combinations of artificial and natural materials. North American Green (1986) gives results of flume tests of several mats used as channel liners, which show 0.25 inch, or less soil loss with flow rates up to $9 \mathrm{ft}^{3} / \mathrm{s}$ on a 12 percent slope. These mats reduce water velocity from 56 to 78 percent and protect grass seedlings until the vegetation becomes firmly rooted in the channel section. One disadvantage to these woven mats is that routine grader maintenance on forest roads may catch the mat and rip it out.

The most common erosion control treatment for roadside ditches is a rock blanket, or riprap. The $\mathrm{D}_{50}$, Dmax, and riprap thickness may be designed as a function of flow rate, channel slope, and channel shape. The design procedure outlined here was based on Highway Research Board Report 108 (Anderson and others 1970) with graphical solutions. These graphs are not convenient to use and their range does not represent forest road conditions. The basic design equations were used to develop a calculator program for a design procedure suitable for forest roads. A flow chart to illustrate the iterative procedure is shown in figure 13. Initial flow depth (d) for trapezoidal channels is estimated by a regression equation solving for $d$ using flow rate, channel slope, channel side slopes, and a Manning's $n$ of 0.03 . The procedure may also be used for

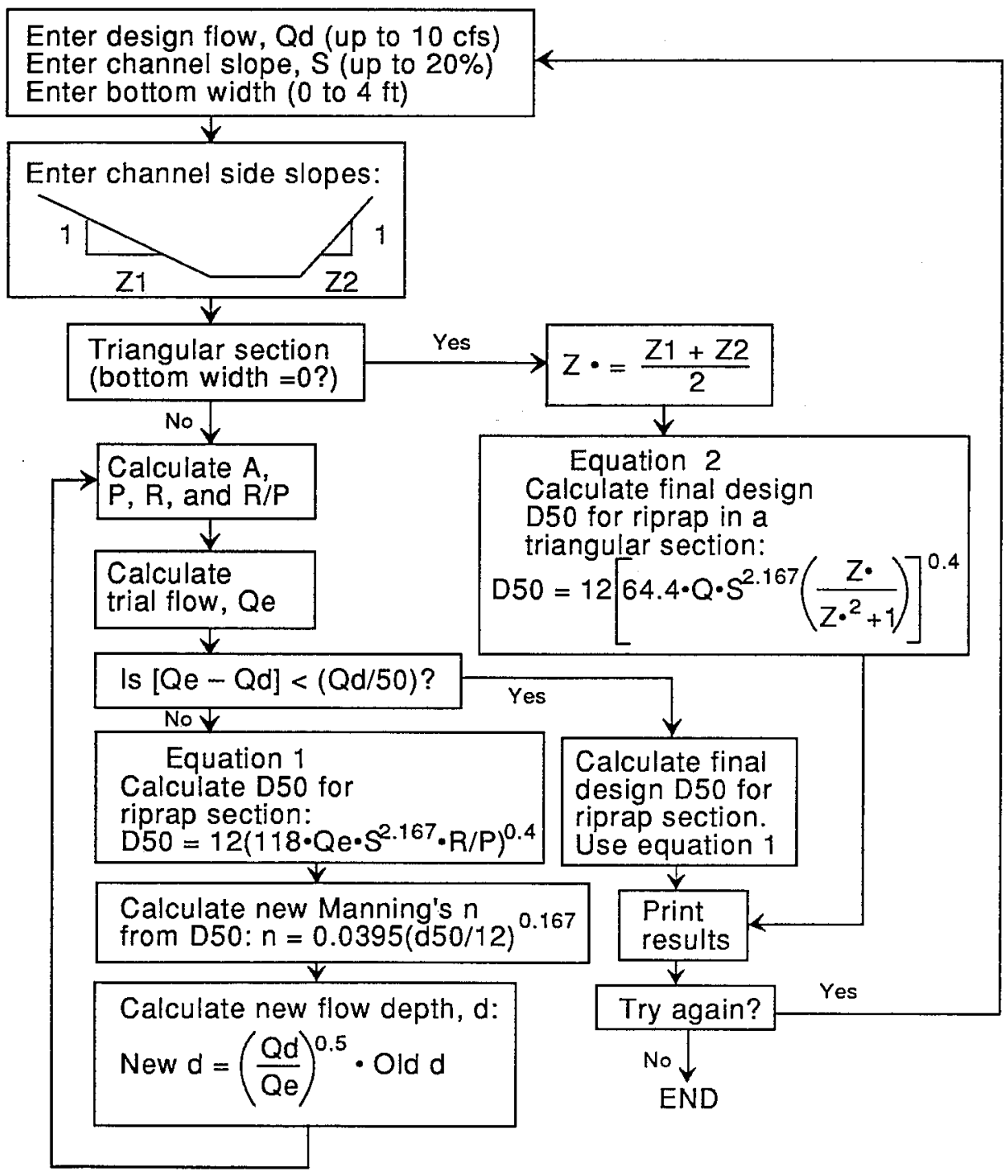

Figure 13- Flow chart for an HP-41 program to calculate riprap $D_{50}$ for road ditches. 
triangular channels. The procedure calculates the required $D_{50}$ for riprap to maintain channel stability for the selected design factors. Copies of this program may be obtained from Burroughs, or the program may be copied from the program listing in the Appendix.

For an example, assume a 500 -ft road section on an 8 percent slope draining to a road crossing. The trapezoidal ditch has a 0.5 -ft bottom width, a 3:1 side slope on the road side, and a 1:1 slope on the cut side. The expected peak flow in the ditch is $0.4 \mathrm{ft}^{3} / \mathrm{s}$. Enter $Q=0.4$, road slope $=8$, bottom width $=0.5$, and the two side slopes, 3 and 1. The calculated $D_{50}$ is 2.4 inches to protect the channel bottom from this discharge on this channel slope.

An Environmental Protection Agency report (1976) recommends that the maximum size of stone in the riprap be 1.5 times $\mathrm{D}_{50}$, or 3.6 inches in this example. This report also recommends that the thickness of the riprap blanket be 1.5 times the maximum rock size, but not less than 6 inches.

Another major consideration in riprap blanket design is whether a filter is required between the riprap and the underlying material (base). If the $D_{50}$ of the base material is too fine relative to the riprap, then flowing water may pull material out of the base and allow the riprap to collapse. A criterion for determining if a filter is required is to compare the $D_{50}$ for the two layers:

$$
\frac{D_{50} \text { Riprap }}{D_{50} \text { Base }}<\begin{gathered}
40 \text { indicates that a filter } \\
\text { will not be needed. }
\end{gathered}
$$

In the example, assume that the base material in which the road and ditch are constructed has a $D_{50}$ of $1.1 \mathrm{~mm}$. The required riprap has a $D_{50}$ of 2.4 inches, or $61 \mathrm{~mm}$. The ratio of these two is $61 / 1.1$ or 55 , which indicates that a filter is needed. One layer of plastic filter cloth is usually sufficient to separate the two materials.

In this example, the road is to be surfaced with crushed rock with an AASHO standard aggregate No. 4, with a $D_{50}$ of about 1 inch. The peak flow rate in the ditch for the upper $150 \mathrm{ft}$ of the road is estimated to be $0.07 \mathrm{ft}^{3} / \mathrm{s}$. The design procedure shows that the required $D_{50}$ for riprap in the ditch is $1.0 \mathrm{inch}$. Therefore, the road surfacing material could be used in the upper $150 \mathrm{ft}$ of road and the larger riprap rock used in the lower $350 \mathrm{ft}$.

\section{Combined Erosion Control on Traveledway, Cutslope, and Ditch}

Little information is available on the integrated effects of mitigation measures applied to separate components of the road prism. Tests by the Intermountain Research Station Engineering Technology project provide some insight into these questions. Simulated rainfall was applied to $100-\mathrm{ft}-$ long bounded sections of forest road built in border-zone gneiss and schist in northern Idaho (Burroughs and others 1983b). One section had a gravelsurfaced traveledway, bare cutslope, and an unprotected ditch. The second section had no protection on traveled- way, cutslope, or ditch. Metal barriers and gutters were used to collect traveledway runoff separately from the combined runoff from the cutslope and ditch. Several rain applications were made on the section with the graveled traveledway and unprotected ditch. Then gravel was placed in the ditch, and several more rainfall applications were made to measure the sediment reduction provided by this treatment. Next, gutters and barriers were removed so that traveledway runoff could enter the ditch, and the total sediment production from the entire section was measured over several rainfall applications. Finally, gravel was removed from the ditch so that total runoff down an unprotected ditch could be measured and the increased sediment production determined. Figure 14 provides our estimate of the combined effects of a gravel road surface with a protected ditch using the results of these barriered and unbarriered tests on both the gravelsurfaced and unprotected section.

The upper curve in figure 14 represents the sediment production to be expected from a 100-foot road section with no gravel on the traveledway or in the ditch, and an unprotected cutslope in border-zone gneiss and granite. The second curve results from a graveled traveledway and an unprotected ditch and cutslope. Reduction in sediment yield from a $100-\mathrm{ft}$ road section with this treatment ranges from 27 percent for the first rainfall application to 40 percent for the last application with an average reduction of 33 percent.

The third curve represents an estimate of reduced sediment production provided by a graveled traveledway and a graveled ditch, relative to an unprotected road section. This reduction ranges from 49 percent for the first rainfall application to 67 percent for the last, with an average reduction of 57 percent. The application of gravel to the ditch in addition to the traveledway reduces sediment production by an average of 24 percent. The gravel used to protect the ditch in these tests was the same material used to surface the traveledway, 1.5-inch minus gneissic rock with $a D_{50}$ of 0.24 inches. The riprap design program estimated a $D_{50}$ of about 1.1 inches for a stable ditch with the flow rate, slope, and ditch shape present on this site. Degradation of the ditch bottom at the lower end of the plot was measured during these tests, which indicates that coarser gravel should have been used to stabilize the ditch bottom. If so, then the reduction in sediment yield provided by graveling the ditch would have been greater than shown by these tests. This also suggests that the unprotected ditch may be a greater source of sediment than the unprotected traveledway, at least for roads with a low traffic volume.

The bottom curve is an estimate of the additional sediment reduction provided by protecting the cutslope. For this estimate, we assumed that the cutslope protection was 80 percent effective and that the graveled ditch did not itself provide any significant sediment. This hypothetical curve was derived by subtracting an additional 80 percent of the sediment production from the graveled $\mathrm{road} / \mathrm{graveled}$ ditch curve. The estimated sediment reduction provided by graveling the traveledway and ditch and protecting the cutslope averages 91 percent. 


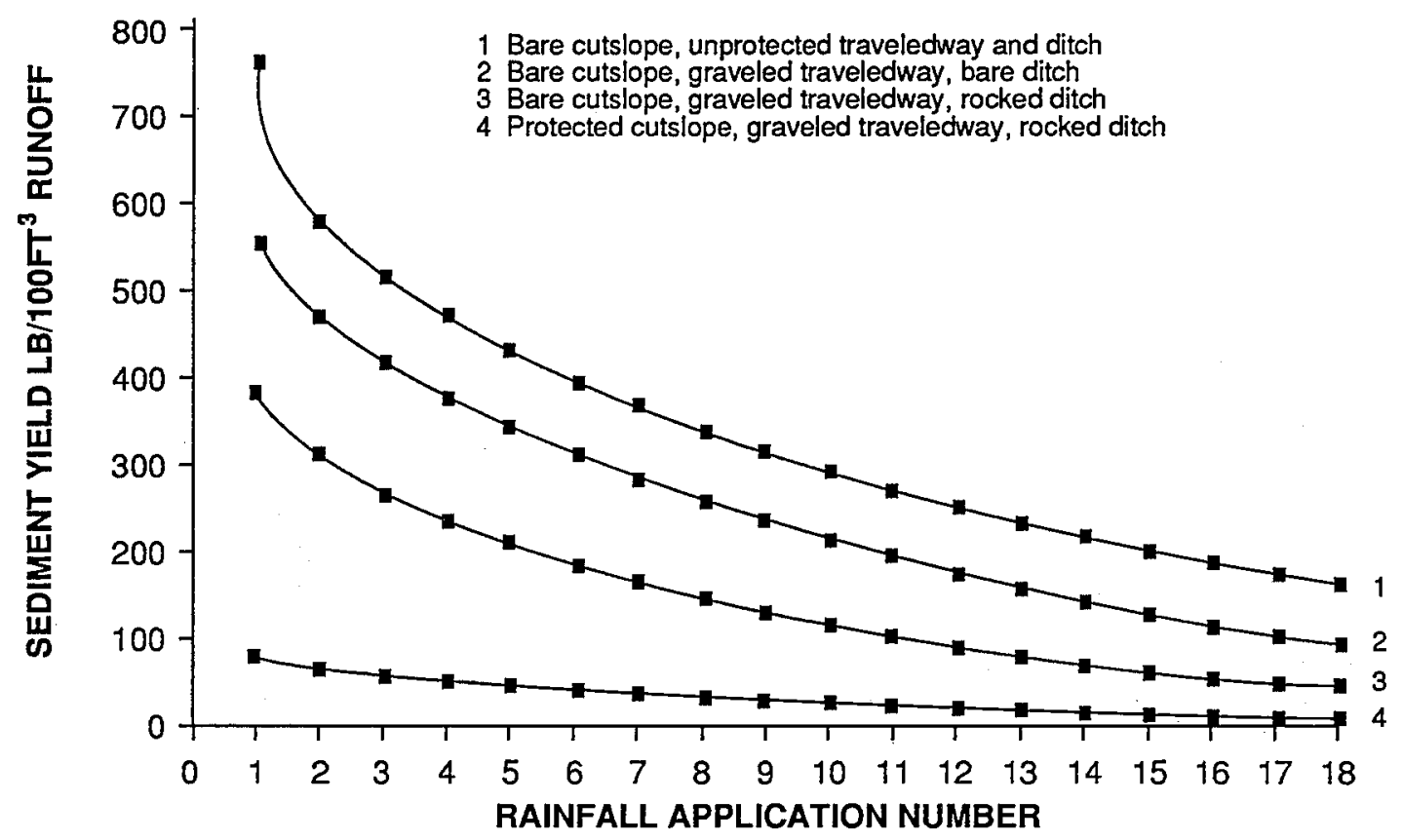

Figure 14-Partitioning of sediment yield between components of the road prism.

Other items should be noted. The effect of surface armoring is quite pronounced as rainfall and runoff detach and remove fine soil particles and cause a progressively coarser surface texture. Keep in mind that these curves result from simulated rainfall on two 100-ft sections of road. Therefore, these results are accurate only for the relative differences in sediment production provided by various mitigation treatments. The values of sediment production in pounds per $100 \mathrm{ft}^{3}$ of runoff should not be used to represent results of natural rainfall or snowmelt.

The results of the simulated rainfall study for partitioning road sediment did not include a bounded section of the fillslope that would have allowed comparison of relative sediment yields between all road features. However, information is available from one instrumented road section at a stream crossing on a similar geology and soils. The road, one of the Horse Creek roads on the Nez Perce National Forest, did not have any erosion control treatments on the cuts or fills, and the road traveledway was unsurfaced. Instruments to measure stream discharge and sediment concentration were installed at three sampling sites along the stream channel (fig. 15): upstream from the road (station $A$ ), at the outfall of the culvert passing the stream (station $\mathrm{B}$ ), and about $150 \mathrm{ft}$ downstream from the road (station C). The road was built in the summer of 1979, and the stations were placed in operation at the end of the summer and continued to operate for 4 years.

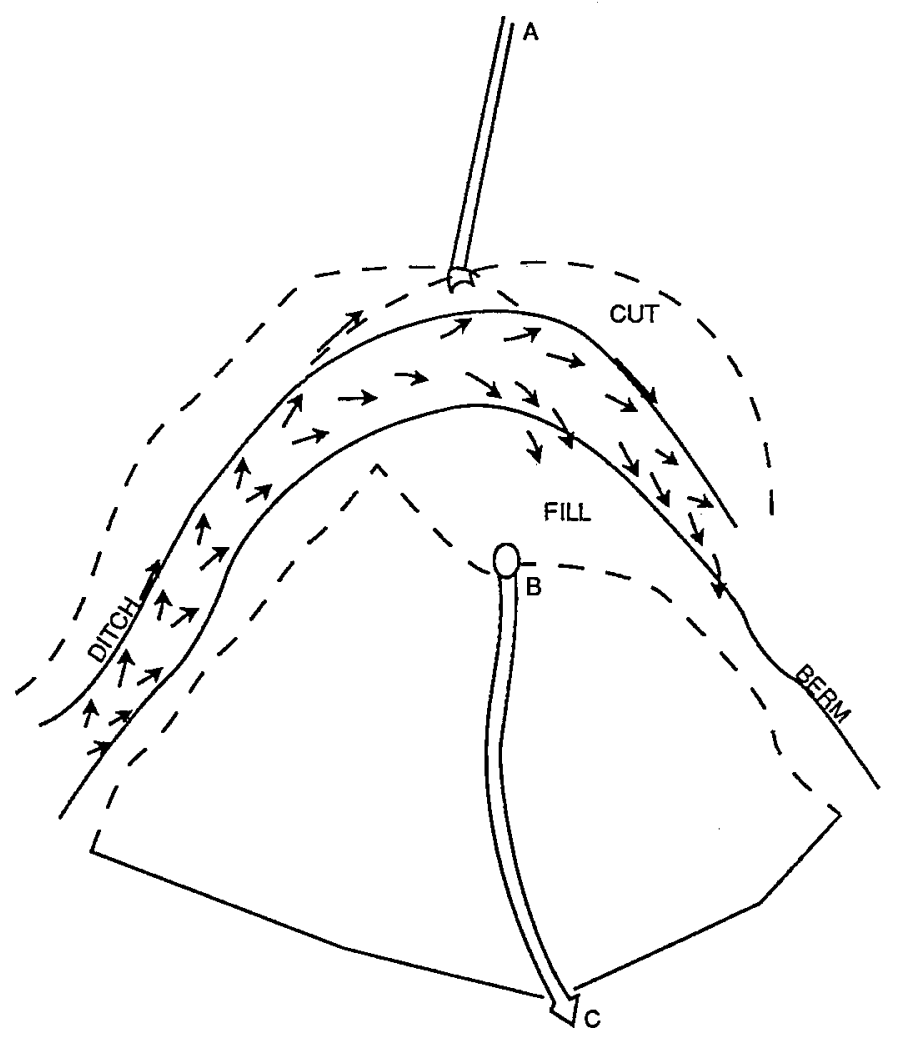

Figure 15-Road features and flow paths for the Horse Creek stream crossing with no erosion control measures. 
These stations allow for partitioning the sediment by that amount contributed via the ditch system and that amount reaching the stream from the fill slope side of the road. The increase in sediment yield between stations $A$ and $B$ is the sediment delivered to the stream via the ditches, which would include eroded material from the cutslopes, ditches, and a portion of the traveledway. The increase in sediment yield between stations $B$ and $C$ is the sediment reaching the channel from the fillslope side of the road, which includes eroded material from the fillslopes and a portion of the traveledway, plus or minus channel storage. Figure 15 shows the road features, drainage flow paths, and contributing areas to the stations.

This road section is unusual in that the traveledway is crowned and drains to both the ditches and the fills. Another unusual feature is a berm along much of the outside edge of the traveledway that carries water along it for some length. This water is then diverted onto the unprotected fills in two locations, one of which is directly above the channel. This berm was not a designed feature in the road but was created during construction and maintenance grading. Table 4 gives the areas of each road feature contributing to the $\mathrm{A}$ and $\mathrm{B}$ stations. Note that the majority (72 percent) of the traveledway that influences this stream drains onto the fillslopes.

The percentage of the total annual stream sediment that is contributed via the ditch or fillslope side of the road varies over time (table 5). During the first year after construction, 80 percent of the sediment reached the stream via the fillslope side of the road. After 4 years the situation is reversed, and 83 percent of the sediment is contributed via the ditch system. Over the entire 4 years, 47 percent of the sediment reached the stream from the fillslope side of the road. These results and supporting measurements of fillslope erosion and observation of sediment and water-flow paths indicate that during the first year following road construction at this stream crossing, the unconsolidated fillslopes near the stream generated the majority of the stream sediment. Fillslope erosion was increased by drainage from the traveledway immediately above the channel.

This case study of a bermed road suggests that during the first year following construction, erosion control measures on the fillslopes or immediately below the fillslopes would be more effective in reducing stream sediment than measures to control cutslope and ditch erosion. However, as the less steep fillslopes become armored and revegetated, then the primary source of sediment is ditch and cutslope erosion. The results also suggest the need to avoid undesigned berms that concentrate traveledway drainage and then divert it onto the fillslopes. Insloping the road to the ditch or a more uniform spacial distribution of traveledway drainage onto the fills would considerably reduce fillslope contributions of stream sediment. This would require care during routine blading to avoid altering the designed traveledway drainage such as creating an undesigned berm along the outside edge of the traveledway.

Table 4-Plan view areas of the road features contributing to $B$ and $\mathrm{C}$ sampling stations

\begin{tabular}{|c|c|c|c|}
\hline Road feature & B station & C station & Total \\
\hline & \multicolumn{3}{|c|}{$\ldots \ldots \ldots \ldots t^{3+} \ldots \ldots \ldots \ldots$} \\
\hline Cutslope & 3,478 & & 3,478 \\
\hline Ditch & 1,104 & & 1,104 \\
\hline Traveledway & 1,875 & 4,847 & 6,722 \\
\hline Fillslope & & 7,503 & 7,503 \\
\hline
\end{tabular}

Table 5-The partitioning of total road sediment entering the stream via the ditch system and the fillslope side of the road for the 4 years following construction

\begin{tabular}{lcccccc}
\hline $\begin{array}{l}\text { Sediment } \\
\text { source }\end{array}$ & \multicolumn{5}{c}{ Years } \\
\cline { 2 - 5 } & 1980 & 1981 & 1982 & 1983 & Average \\
\hline & 20 & 48 & 60 & 83 & 53 \\
$\begin{array}{l}\text { Via the ditch } \\
\begin{array}{l}\text { Via the fillslope } \\
\text { side of the road }\end{array}\end{array}$ & 80 & 52 & 40 & 17 & 47 \\
$\begin{array}{l}\text { Total road sediment } \\
\text { at C station, lb }\end{array}$ & 2,492 & 2,132 & 6,997 & 1,317 & \\
\hline
\end{tabular}




\section{CONCLUSIONS}

This paper provides land managers with a summary of the effectiveness of various road treatments and practices in reducing erosion and sediment transport. We have not included an exhaustive summary of all related research, but we have provided information to improve estimation of sediment yield from roads and to improve the decisionmaking process. Again, experience and professional judgment are required in relating many of these results to local situations.

Development continues on methods to reduce onsite erosion from forest roads. This research is now part of a Forest Service study of onsite erosion from roads and disturbed forest sites nationwide. The goal of this longterm study is to develop a physical process model of onsite erosion using easily measured site characteristics with user-selected hydrologic events to evaluate alternative land management treatments. This effort to develop a forest onsite sediment model is part of a larger cooperative effort with the U.S. Department of Agriculture, and Agricultural Research Service, Soil Conservation Service, and U.S. Department of the Interior, Bureau of Land Management, to predict soil erosion from croplands, rangelands, and forests.

\section{REFERENCES}

Anderson, A. G.; Paintal, A. S.; Davenport, J. T. 1970. Tentative design procedure for riprap-lined channels. National Highway Research Program Report 108. Washington, DC: National Academy of Sciences, Highway Research Board. 75 p.

Barnett, A. P.; Diseker, Ellis G.; Richardson, E. C. 1967. Evaluation of mulching methods for erosion control on newly prepared and seeded highway backslopes. Agronomy Journal. 59: 83-85.

Bethlahmy, N.; Kidd, W. J., Jr. 1966. Controlling soil movement from steep road fills. Res. Note INT-45. Ogden, UT: U.S. Department of Agriculture, Forest Service, Intermountain Forest and Range Experiment Station. 4 p.

Boise State University. 1984. Project completion report: sediment yield from cut and fill slopes: Silver Creek research evaluation: Boise National Forest, Idaho. Cooperative Agreement INT-80-003-CA. Boise, ID: Boise State University, Department of Geology and Geophysics. 96 p.

Burroughs, E. R., Jr.; Haber, D. F.; Watts, F. I.; Kadoch, T. L. 1983a. Measuring surface erosion on forest roads and estimating costs of erosion control-preliminary results. In: Low volume roads: Third international conference, 1983. Transportation Research Record 989. Washington, DC: National Academy of Sciences, Transportation Research Board: 214-221.

Burroughs, E. R., Jr.; King, J. G. 1985. Surface erosion control on roads in granitic soils. In: Jones, E. B.; Ward, T. J., eds. Watershed management in the eighties: Proceedings; 1985 April 30-May 1; Denver, CO. [New York]: American Society of Civil Engineers: 183-190.
Burroughs, E. R., Jr.; Watts, F. J.; Haber, D. F. 1984. Surfacing to reduce erosion of forest roads built in granitic soils. In: O'Loughlin, C. L.; Pearce, A. J., eds. Proceedings symposium on effects of forest land use on erosion and slope stability. 1984 May 7-11; Honolulu, HI. Honolulu, HI: University of Hawaii, East-WestCenter: 255-264.

Burroughs, E. R., Jr.; Watts, F. J.; King, J. G.; Haber, D. F.; Hansen, D.; Flerchinger, G. 1983b. Measurement of the relative effectiveness of rocked roads and ditches in reducing surface erosion, Rainy Day Road, Nez Perce National Forest, Idaho. Unpublished report on file at: U.S. Department of Agriculture, Forest Service, Intermountain Research Station, Forestry Sciences Laboratory, Moscow, ID. 25 p. plus appendixes.

Burroughs, E. R., Jr.; Watts, F. J.; King, J. G.; Haber, D. F.; Hansen, D.; Flerchinger, G. 1985a. Relative effectiveness of rocked roads and ditches in reducing surface erosion. In: Proceedings of the 21st annual engineering geology and soils engineering symposium; 1984 April 5-6; Moscow, ID. Moscow, ID: University of Idaho, Department of Civil Engineering: 251-263.

Burroughs, E. R., Jr.; Watts, F. J.; King, J. G.; Hansen, D. $1985 \mathrm{~b}$. Relative effectiveness of fillslope treatments in reducing surface erosion, Horse Creek Road, Nez Perce National Forest, Idaho. Unpublished report on file at: U.S. Department of Agriculture, Forest Service, Intermountain Research Station, Forestry Sciences Laboratory, Moscow, ID. 34 p.

Carlton, M. M.; King, J. G.; Tennyson, L. C. 1982. On-site erosion on natural and disturbed soils, and natural bedload sediment production in first-order drainages in the Gospel Hump Area. Completion report, Cooperative Research Agreement INT-80-115-CA with the U.S. Department of Agriculture, Forest Service, Intermountain Research Station, Ogden, UT, and the College of Forestry, Wildlife and Range Sciences, University of Idaho, Moscow, ID. $97 \mathrm{p}$.

Cline, R.; Cole, G.; Megahan, W.; Patten, R; Potyondy, J. 1981. Guide for predicting sediment yields from forested watersheds. Ogden, UT: U.S. Department of Agriculture, Forest Service, Northern and Intermountain Region and Intermountain Forest and Range Experiment Station. 42 p.

Cook, M. J.; King, J. G. 1983. Construction cost and erosion control effectiveness of filter windrows on fillslopes. Res. Note INT-335. Ogden, UT: U.S. Department of Agriculture, Forest Service, Intermountain Forest and Range Experiment Station. 5 p.

Dudeck, A. E.; Swanson, N. P.; Dedrick, A. R. 1967. Mulch performance on steep construction slopes. Rural and Urban Roads. May 1967. 4 p.

Dyrness, C. T. 1975. Grass-legume mixtures for erosion control along forest roads in western Oregon. Journal of Soil and Water Conservation. 30(4): 169-173.

Environmental Protection Agency. 1976. Erosion and sediment control. Surface mining in the eastern United States. Vol. 2, Design. Cincinnati, OH: Office of Technology Transfer. $243 \mathrm{p}$. 
Goss, Roy L.; Blanchard, R. M.; Melton, W. R. 1970. The establishment of vegetation on non-topsoiled highway slopes in Washington. Final Report. Pullman, WA; Washington State Highway Commission, Washington State University Agricultural Research Center. 14 p.

Gulf States Paper Corp. 1977. Report of sediment yield tests with HOLD/GRO erosion control fabric and competitive erosion control products. Vance, AL. 18 p.

Kay, Burgess L. 1984. Mulches aid plant establishment and erosion control on disturbed sites. Paper presented at Soil Erosion and Sedimentation Short Course, Washington State University Cooperative Extension, Olympia, WA; 1984 February 22-23. 24 p.

Kennedy, R. 1986. [Personal communication]. Grangeville, ID: U.S. Department of Agriculture, Forest Service, Nez Perce National Forest, Engineering Staff.

King, J. G. 1984. Ongoing studies in Horse Creek on water quality and water yield. Tech. Bull. 435. New York: National Council of the Paper Industry for Air and Stream Improvement: 28-35.

King, John G. 1979. Fillslope erosion from forest roads. In: Proceedings, 34th meeting, 1979 October 3-5; Boise, ID. Pap. 79-404. St. Joseph, MI: American Society of Agricultural Engineers. 11 p.

King, John G.; Gonsior, Michael. 1980. Effects of forest roads on stream sediment. Unpublished manuscript on file at: U.S. Department of Agriculture, Forest Service, Intermountain Research Station, Forestry Sciences Laboritory, Moscow, ID. 19 p.

Kochenderfer, J. N.; Helvey, J. D. 1987. Using gravel to reduce soil losses from minimum-standard forest roads. Journal of Soil and Water Conservation. 42: 46-50.

Megahan, W. F. 1974. Erosion over time on severely disturbed granitic soils: a model. Res. Pap. INT-156. Ogden, UT: U.S. Department of Agriculture, Forest Service, Intermountain Forest and Range Experiment Station. $14 \mathrm{p}$.

Megahan, W. F. 1978. Erosion processes on steep granitic roadfills in central Idaho. Journal of Sojl Science Society of America. 42: 350-357.

Megahan, W. F. 1984. Road effects and impacts-Watershed. In: Proceedings, forest transportation symposium; 1984 December 11-13; Casper, WY. Lakewood, CO: U.S. Department of Agriculture, Forest Service, Rocky Mountain Region, Engineering Staff Unit; 1985: 57-97.
Meyer, L. D.; Wischmeier, W. H.; Foster, G. R. 1970. Mulch rates required for erosion control on steep slopes. Journal of Soil Science Society of America. 34: 928-931.

Meyer, L. D.; Johnson, C. B.; Foster, G. R. 1972. Stone and wood chip mulches for erosion control on construction sites. Journal of Soil and Water Conservation. 27: 264-269.

North American Green. 1986. Erosion control blankets. Evansville, IN: North American Green. 18 p.

Ohlander, C. A. 1964. Effects of rehabilitation treatments on the sediment production of granitic road materials. Fort Collins, CO: Colorado State University. 78 p. Thesis.

Rothwell, R. L. 1983. Erosion and sediment control at road-stream crossings. The Forestry Chronicle. 59: 62-66.

Swift, L. W., Jr. 1984a. Gravel and grass surfacing reduces soil loss from mountain roads. Forest Science. $30(3): 657-670$.

Swift, L. W., Jr. 1984b. Soil losses from roadbeds and cut and fill slopes in the southern Appalachian Mountains. Southern Journal of Applied Forestry. 8(4): 209-213.

Swift, L. W., Jr. 1985. Filter strip widths for forest roads in the southern Appalachians. Southern Journal of Applied Forestry. 10(1): 27-34.

Swift, L. W., Jr. 1987. [Personal communication]. U.S. Department of Agriculture, Forest Service, Coweeta Hydrologic Laboratory, Otto, NC.

Tour, J. W. 1985. Revegetating slopes with geotextile and geogrid systems. U.S. Department of Agriculture, Forest Service, Equipment Development Center, Missoula, MT. $58 \mathrm{p}$.

Wagner, M.; Egan, J.; Wain, G. F.; Howell, R. B. 1979. Erosion measurements on a smooth and stepped highway slope (District 11). Interim Report 19703-657108. Sacramento, CA: California Department of Transportation, Office of Transportation Laboratory. $49 \mathrm{p}$.

Wischmeier, W. H.; Smith, D. D. 1965. Predicting rainfallerosion losses from cropland east of the Rocky Mountains. Agric. Handb. 282. Washington, DC: U.S. Department of Agriculture. $47 \mathrm{p}$.

Wollum, A. G., II. 1962. Grass seeding as a control for road bank erosion. Res. Note PNW-218. Portland, OR: U.S. Department of Agriculture, Forest Service, Pacific Northwest Forest and Range Experiment Station. 5 p. 


\section{Road Ditch Cross Section}

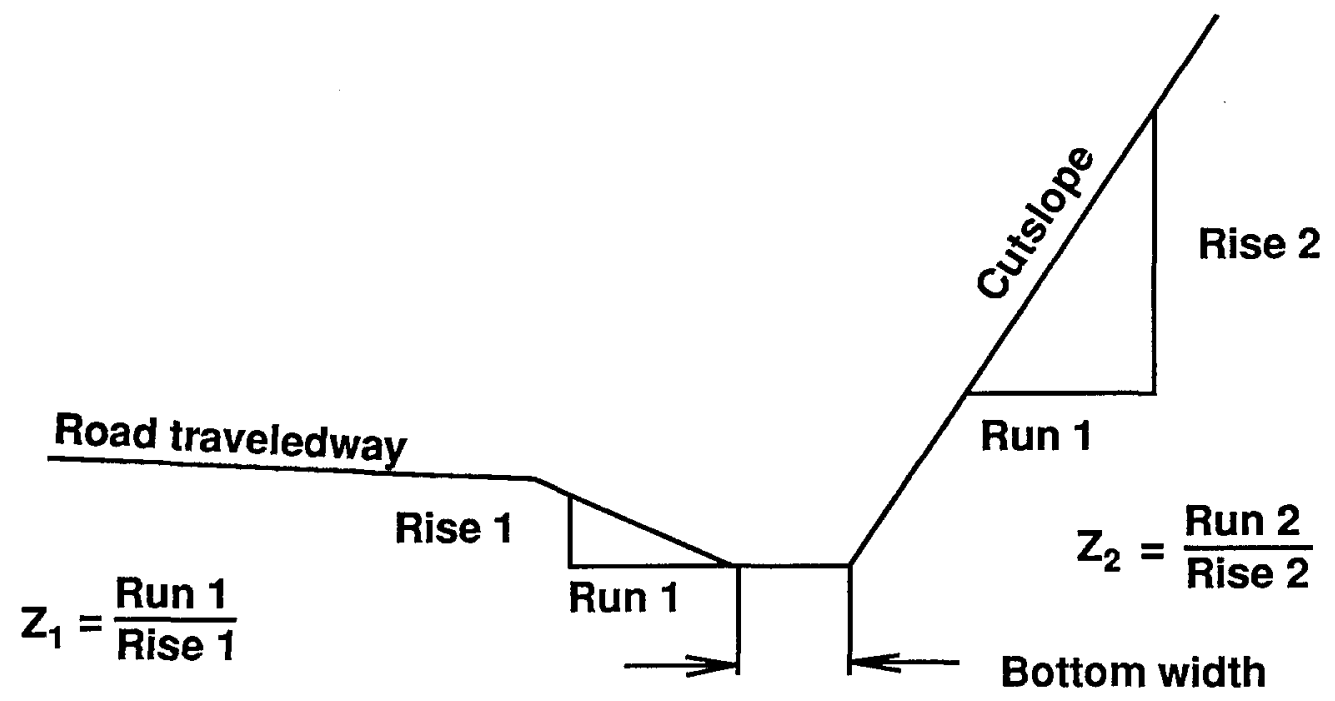

(Use a bottom width $=0$ for triangular ditch cross sections.)

\section{Example Calculations}

Example 1

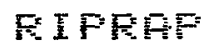

IEESIE章 HASCH 1989

4. $\mathrm{AF}=\mathrm{B}=\mathrm{B}$

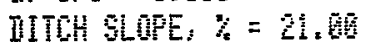

SLOFE ? 2G: TRI HOHM

DITCH SLEE, $z_{2}=z_{2}, 09$

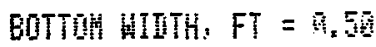

21 = WULAISEI= 3.64

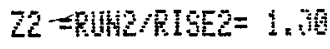

15G= $2.23 \mathrm{IH}$

Example 2

FIFFAF

IIESIGL

AHECH 195

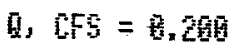

DITCH SLIRE, $\gamma=g$.

BOTTOA HDTH, FT $=\bar{b} .0 \overline{6}$

$Z 1=$ FIH $1 / \mathrm{EISEI}=3.45$

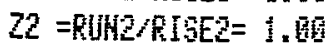

$156=2.59$ IH.

EHIJ

\section{Program Printout}

6I+LEL = EIFAPF"

$\theta_{i}$ of 12

63: RIFEAF"

64 YEE "PRA"

65 - IESIGH=

Q6. $\mathrm{XEQ}$ "PEH"

$97 \mathrm{of} 2$

68 .

HOFE I9=

69 "F 199

15. KEE "PRF"

$11+$ LDL "Ti"

12 GDV

13 I

$14 \mathrm{CF}$

$15 \mathrm{CF}$

$16 . \overline{16} \overline{3}$

$179 T 0$

$10 \div 5 \frac{7}{3}$

$19-0,055=$

26 FEUAT

21 "

22 UEA "ALC"

23 YEA "PFEUF"

24 STO 
$25+\mathrm{LBL} \quad \mathrm{C} \mathrm{C}^{\prime \prime}$

2629

$27 \mathrm{FIN} 2$

28 = IITCH SLOFE, $\%=$

$29^{\prime \prime}=$

30 PROAFT

31 XEE "HิCA"

$32 \mathrm{XEQ}$ "

33 XED "FEDLF"

$345 \mathrm{TO} 62$

$35 \mathrm{~W}=\mathrm{W}$ ?

36 GTu $\mathrm{E}$

$37 \pm L E L=01$

38 "SLOPE > 2E: TEY"

39 "十 HCFIH"

4 A AIE:

$41 \mathrm{GTO}=\mathrm{C}^{\mathrm{x}}$

$4 \bar{L}+\mathrm{L} \overline{\mathrm{E}} \mathrm{L} \mathrm{E}$

$43 \mathrm{SF}$

44 "EOTTOH HIDTH: F"

$45 \times 1=$

46 PROAPT

$47 \mathrm{MEO}=\mathrm{ACOH}$

$40 \mathrm{HEO}$ "HCF"

49 敬 $=F E D I F=$

$50 \mathrm{STO} 63$

51

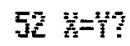

$53 \mathrm{TN}=\mathrm{TEI}$

단 $\mathrm{wh}$

5 )

56 Wh

$57+\mathrm{LEL}$ "TREF"

58.2733

59 利是

$66 \mathrm{ECL} 1$

$61-.9279$

$62 \mathrm{Hin}$

$6 \%$

$64=2723$

$65 *$

$66 \mathrm{CHS}$

$67 \mathrm{NOL} \mathrm{D2}$

$60 \mathrm{x}$

$69 \mathrm{ith}$

$7 \mathrm{FCL}$

$71-\frac{2}{4} 59$

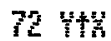

$73 \mathrm{FCL}$

$7 \overline{4} .536 \overline{5}$

75 彭诸

$76 *$

77.3245

78 *

$79 *$
$805 T 064$

81 GTO *

82+LEL "TEI"

83 sf 01

\section{4*LEL "g"}

85 "Z1 =RUH1 $/ \mathrm{RISE}="$

66 PROLFT

87 UET "ACA"

89 XE "MCH"

69 YEA "FEDIF"

$90 \cdot 72=\mathrm{RLH} / \mathrm{KISR}==$

91 PRDHPT

92 XED "ĀCH"

$93 \mathrm{XEL}$ "THC"

94 YEI "FESUF"

$95 \div$

962

पो

$985 T 06$

$95 \mathrm{Fs}$ है

$106070-12$

1 G1 + LEL

$102 \mathrm{MO}$

$163 \mathrm{FD}$ 酰

164

IDS FI B

$166 \div$

$107 \mathrm{miL}$

ing

ing sTu

$11 \overline{6}+\mathrm{LE}=\mathrm{E}=$

$11 \mathrm{~mL}$ 月⿺辶

1122

117

$114 \mathrm{FCL}$

III

1161

$117 \div$

$118 \mathrm{set}$

$11 \% \neq$

126 Wh

$121 \div$

122 sाँ

$123+\mathrm{LEL}$ "R:"

124 ;

125 जाए 6

$126 * \mathrm{LEL}=\mathrm{R} / \mathrm{F}$

127 net 67

120 .

12950107

136i

1311.456

$132 \mathrm{FCL}$ 
$135 \%$

$134 \mathrm{MO} 6 \mathrm{G}$

135.567

136 논

$137 \div$

$13 \overline{\mathrm{nLL}}$

139 195

146

141 54

$142 \%$

$143 \mathrm{~min}$

144 :

$145 \mathrm{STI}$ पू

$146 \mathrm{FSCO}$

147 inT "III"

14르 $\mathrm{FCL}$

$145 \mathrm{5E}$

$15 \overline{6}$;

$151 \mathrm{RCL} 69$

$152 \mathrm{ECL}$ OI

157 -

$154 \mathrm{ABS}$

$155 y=4$ ?

156 of

15T+LEL "III"

$150 \mathrm{FC}$

159110

$160 \%$

$161 \mathrm{PA}$ b

16210

163 ;

1642.1667

$165 \mathrm{~T}+\mathrm{TH}$

166 *

$167 \mathrm{FCL}$

169

$169 \times 4$

170 翼是

171 GT0 "

$172+\mathrm{LEL}$ "T2"

$173 \mathrm{FCL}$

$17464=4$

$175 *$

$176 \mathrm{KaL}$

177160

$175 \%$

$1792 \times 1667$

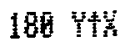

181 *

$102 \mathrm{RH}$ -

$183 \mathrm{RCL}$ 酧

$184 \mathrm{xt2}$

1851

$186 \div$

187 \%

$180 *$

$189-4$
14 พิ⿱亠䒑十纟

1915010

192 of

$193 \mathrm{GT}$

$194+\mathrm{LEL}=$

19550 in

196 Fon

$19 \mathrm{gm}$

195.1657

199

$20 \%$. 595

2द⿱

$2 \mathrm{QH} \mathrm{ST}$

203*LEL "HIE"

204 Fil

205 NTL

206 ?

$2075 \mathrm{ST}$

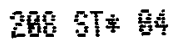

209 जाप म

ZIE+LBL $\overline{1}$

211 सू 16

212 12

$21 \overline{3}$

$21 \frac{14}{4}=515=$

215 WE "MD"

216 WNL

217 HED $=4 \%$

$218=111=$

219 WE "fon"

220 YEI "FREIF"

$221+\mathrm{L}$ [ "

222 "TEV म̈LAH? Y OR"

223 :

2240101

225 PRUAPT

226 AOFE

27 กTU

227

$229 \mathrm{x}=\mathrm{W}$

230 0T0 35

231 $\mathrm{kH}$

2328

$233 y=\%$

$234 \mathrm{Tn}^{\mathrm{BS}}$

235 670 "g"

$236 \div$ LBL 99

237 =EHIE

238 AUIEH

239 STOF

24Q . ENT. 
Burroughs, Edward R., Jr.; King, John G. 1989. Reduction of soil erosion on forest roads. Gen. Tech. Rep. INT-264. Ogden, UT: U.S. Department of Agriculture, Forest Service, Intermountain Research Station. 21 p.

Presents the expected reduction in surface erosion from selected treatments applied to forest road traveledways, cutslopes, fillslopes, and ditches. Estimated erosion reduction is expressed as functions of ground cover, slope gradient, and soil properties whenever possible. A procedure is provided to select rock riprap size for protection of the road ditch.

KEYWORDS: surface erosion, erosion reduction, forest roads

\section{INTERMOUNTAIN RESEARCH STATION}

The Intermountain Research Station provides scientific knowledge and technology to improve management, protection, and use of the forests and rangelands of the Intermountain West. Research is designed to meet the needs of National Forest managers, Federal and State agencies, industry, academic institutions, public and private organizations, and individuals. Results of research are made available through publications, symposia, workshops, training sessions, and personal contacts.

The Intermountain Research Station territory includes Montana, Idaho, Utah, Nevada, and western Wyoming. Eighty-five percent of the lands in the Station area, about 231 million acres, are classified as forest or rangeland. They include grasslands, deserts, shrublands, alpine areas, and forests. They provide fiber for forest industries, minerals and fossil fuels for energy and industrial development, water for domestic and industrial consumption, forage for livestock and wildlife, and recreation opportunities for millions of visitors.

Several Station units conduct research in additional western States, or have missions that are national or international in scope.

USDA policy prohibits discrimination because of race, color, national origin, sex, age, religion, or handicapping condition. Any person who believes he or she has been discriminated against in any USDA-related activity should immediately contact the Secretary of Agriculture, Washington, DC 20250. 